\title{
Impacts of culture-wise shrimp farming activities on hydrogeochemistry: a case study from Chidambaram taluk, Cuddalore district, Tamil Nadu, India
}

\author{
Gangadharan Rajendran ${ }^{1} \cdot$ Nila Rekha Peter ${ }^{2}$
}

Received: 8 May 2017 / Accepted: 8 November 2019 / Published online: 23 November 2019

(c) The Author(s) 2019

\begin{abstract}
Shrimp farming is one of the most important aquaculture practices in terms of area, production, employment and foreign exchange generation in India. In recent years, the growth and intensification of shrimp farms in the study area have been explosive, and setting up of new shrimp farms along the coastal areas has also become a matter of apprehension among the environmentalists. An extensive survey made by environmentalists elsewhere shows mixed opinion, but ascertains the real scenario as facts. A total of about 46 groundwater samples were collected in five phases: pre-culture, summer culture, immediately after summer harvest (IASH), winter culture and immediately after winter culture, respectively. The results revealed that the high value of TDS, $\mathrm{Na}, \mathrm{Cl}$ and $\mathrm{Br}$ is observed in IASH, and also, the spatial distribution map confirmed that higher concentration is observed near to the creek and sea. Moreover, the abundance of these ions is in the following order: $\mathrm{Na}>\mathrm{Ca}>\mathrm{Mg}>\mathrm{k}$ and $\mathrm{Cl}>\mathrm{HCO}_{3}>\mathrm{SO}_{4}>\mathrm{CO}_{3}>\mathrm{NO}_{3}>\mathrm{Br}$ for different culture periods, respectively. Piper diagram depicts that the groundwater was controlled by ion exchange reactions. Further, Chadha's classification revealed that the reverse ion exchange was the dominated feature, and it is supported by various ionic indices such as $\mathrm{Na} / \mathrm{Cl}$ versus $\mathrm{EC},(\mathrm{Ca}+\mathrm{Mg})$ versus $\left(\mathrm{SO}_{4}+\mathrm{HCO}_{3}\right),(\mathrm{Na}-\mathrm{Cl})$ versus $\left(\mathrm{Ca}+\mathrm{Mg}-\mathrm{HCO}_{3}-\mathrm{SO}_{4}\right),(\mathrm{Ca}+\mathrm{Mg})$ versus $\mathrm{Cl}$ and $\mathrm{Na} / \mathrm{Cl}$ versus $\mathrm{Cl}$, respectively. The result of factor analysis shows that most of the variations are elucidated by the seawater intrusion, rock-water interactions and anthropogenic activities during different culture periods. The spatial distribution map of factor scores clearly delineates that the positive values are observed near to the creek and sea and in that, shrimp farming area is not predominated. R-mode cluster analysis shows that groundwater quality does not vary extensively as a function of culture periods. Moreover, Q-mode classification consists of two clusters: the first cluster has a high saline water concentration comprising samples location near to the creek and sea. The second cluster mainly depends upon rock-water interactions and the majority of shrimp farming area are grouped under these categories. The above statements clearly indicate that groundwater parameters mainly depend upon the geological process and that shrimp farming cannot be targeted as the root cause for groundwater salinization.
\end{abstract}

Keywords Hydrogeochemistry $\cdot$ Groundwater quality $\cdot$ Shrimp farming $\cdot$ Culture period

\section{Introduction}

Gangadharan Rajendran

ganga.ciba@gmail.com

1 Department of Geology, Faculty of Natural and Computational Science, Bule Hora University, P.O. Box No: 144, Bule Hora, Oromia Region, Ethiopia

2 Central Institute of Brackishwater Aquaculture, 75, Santhome High Road, R.A. Puram, Chennai 28, India
Aquaculture is one of the important coastal activities in developing countries regarding alleviating poverty and generation of wealth. World aquaculture production during 2013 was 97.2 million tonnes with an estimated total value of US $\$ 157$ billion (Rekha et al. 2017). In India, shrimp aquaculture has shown a rapid growth in the last decade and expanded from 65,100 ha in 1990 to $1,91,074$ ha in 2005-2006, and the average annual growth rate is about $10 \%$ since 1984 . The overall export of shrimp farming in 2013-2014 was to the tune of 3, 01,435 MT worth of US\$ 3210.94 million (MPEDA 2014). Thus, coastal shrimp 
culture contributes significantly to the progress of country's economy as well as the economic well-being of the rural poor. It mainly depends on the availability of good quality of saline water from the sea or creek or backwaters. Benefit of aquaculture is more in a positive manner; many reviews lead one to conclude that aquaculture had only a positive impact on environments (Phillips et al. 1993; Newport and Jawahar 1995). However, there will be some negative impacts including salinization of drinking water and aquifers (Patil et al. 2002). Similarly, in the study area, the rapid development of shrimp culture has been accompanied by many controversies, resulting in a closer look at the environmental problems, but till now there is no accurate method to point out that shrimp farms are the main reason for influencing the salinity of water in groundwater aquifers. The pollution caused by the water discharged from the shrimp farms is a big matter of concern, which is responsible for the conflicts between shrimp farmers and environmentalists in the study area. Water with the required quality and quantity is required for different stages of shrimp farming. In the shrimp hatchery, unpolluted seawater is required for brood stock maintenance, spawning, larval rearing and culture of food organism. The grow-out farm ponds need sea/brackish water, free from agriculture, domestic and industrial pollution and also within the required salinities, $\mathrm{pH}$ and temperature ranges (Saraswathy et al. 2016). The fact understood is that the effect of pollution from shrimp farm effluent is considerably less than that of domestic or industrial wastewater. However, the quality of water and even the impacts from external environmental changes pose a threat to the sustainability of shrimp culture. Therefore, environmentalist made an opinion that the deterioration of drinking water quality is due to shrimp culture in coastal habitats, but it is not true since seawater intrusion is also found to attribute salinization in the study area.

However, the previous work indicates that groundwater quality in the study area is largely determined by natural processes such as groundwater velocity, dissolution and precipitation of minerals, quality of recharge waters, water-rock interaction and anthropogenic activities (Chidambaram et al. 2010; Prasanna et al. 2011 and Rekha et al. 2013). A continuous monitoring of the groundwater in shrimp farming does not impact the groundwater quality, and it mainly depends upon the natural process (Rekha et al. 2015; Gangadharan et al. 2016). GIS and remote sensing offer a better option to evaluate the impact on both spatial and temporal variabilities in the study area for assessing the groundwater quality and land-use changes in and around shrimp farming area (Rekha et al. 2017). In coastal aquifer, the hydrogeochemistry of the groundwater varies seasonally and spatially, depending on the influence of lithology, nature of geochemical reactions, velocity and quantity of groundwater flow, solubility of salts and human activities (Janardhana Raju 2006). In this context, this study envisaged that the culture-wise evaluation of groundwater quality in shrimp farming area has not been studied in a great deal. Hence, it is apparent to characterize the hydrogeochemical processes that are responsible for groundwater geochemistry in the study area for different culture periods using Piper plot, ion exchange reactions, Chadha's classification and statistical analysis.

\section{Study area}

The area selected for this study is located in Chidambaram taluk, Cuddalore district, eastern part of Tamil Nadu, Southern India, and comprises sedimentary formation bounded by Bay of Bengal. This area occurs within the Survey of India toposheet no. $58 \mathrm{M} / 10,58 \mathrm{M} / 11,58 \mathrm{M} / 12,58 \mathrm{M} / 13$, $58 \mathrm{M} / 14,58 \mathrm{M} / 15$ in the scale: $1: 50,000$ and is located between $11^{\circ} 30^{\prime} \mathrm{N}$ to $11^{\circ} 20^{\prime} \mathrm{N}$ latitude and $79^{\circ} 38^{\prime} \mathrm{E}$ to $79^{\circ} 48^{\prime} \mathrm{E}$ longitude. The shrimp farming area is covered within three adjacent mini-watersheds with two in Lower Vellar subwatershed $(4 \mathrm{C} 1 \mathrm{~A} 1 \mathrm{c} 4 \mathrm{a} 4$ and $4 \mathrm{C} 1 \mathrm{~A} 1 \mathrm{c} 3 \mathrm{~b} 1)$ and one in Colleroon watershed (4B1A5a1b1e). The watershed boundary has been delineated using toposheet and satellite data as well as with the help of mini- and micro-watershed boundary in the sub-basin collected from Agricultural Engineering Department, Tamil Nadu. The total extent of the study area is about $213.44 \mathrm{~km}^{2}$ in which the water spread area of shrimp farms is approximately $4 \mathrm{~km}^{2}$ (Fig. 1). The study area consists of sedimentary formations, which include sandstone, clay, alluvium and small patches of laterite soils of quaternary age.

\section{Methodology}

Field investigations were carried out from October 2011 to October 2013 by collecting the 46 groundwater samples from hand pumps representing the entire study area. The water samples were collected in pre-cleaned, sterilized polyethylene bottles of 1 litre capacity. Electrical conductivity (EC), $\mathrm{pH}$ and temperature were measured directly in the field using portable multiparameter. Water concentrations such as sodium, potassium, calcium, magnesium, chloride, bicarbonate, carbonate, sulphate, nitrate, bromide and total dissolved solids (TDSs) were carried out by using standard procedures (APHA 2005). The analytical precision for the measurements of cations and anions was indicated by the ionic balance error, which was computed on the basis of ions expressed in milliequivalent per litre. The values were observed to be within a standard limit of $\pm 5 \%$ (Domenico and Schwartz 1998). This study is mainly focussed on the impact of groundwater quality during different culture periods. According to Murugesan et al. 2009, the aquaculture experts' opinion and field observation, there were two crops, 
Fig. 1 Map of the study area along with the locations of the monitoring wells

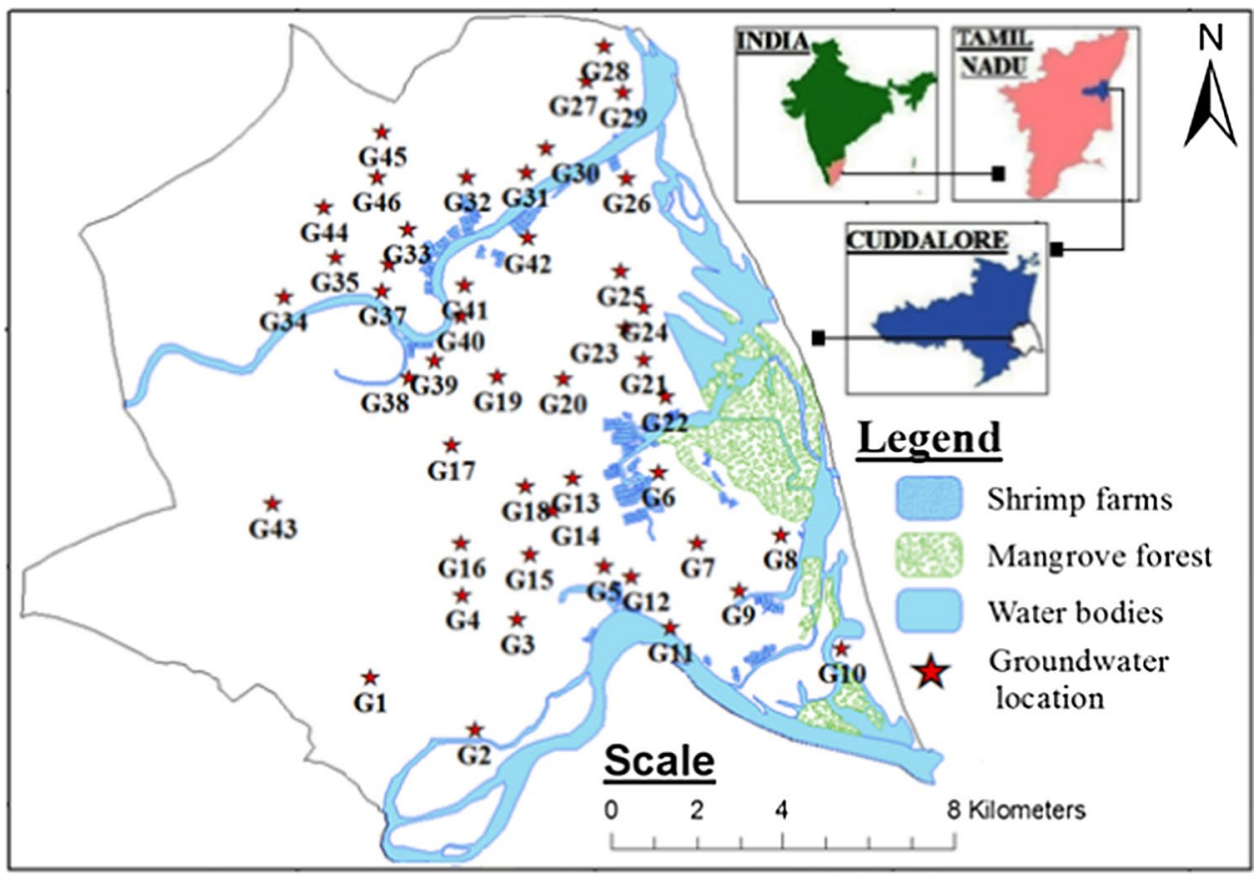

such as summer crop and winter crop, being undertaken in the study area by the shrimp farmers (Table 1). Accordingly, five classifications such as pre-culture (PC), summer culture (SC), immediately after summer harvest (IASH), winter culture (WC) and immediately after winter culture (IAWH) have been made, and analysis was carried out. MS Excel spreadsheet was used to create the Chadha's classification, $\mathrm{Na} / \mathrm{Cl}$ versus $\mathrm{EC},(\mathrm{Ca}+\mathrm{Mg})$ versus $\left(\mathrm{SO}_{4}+\mathrm{HCO}_{3}\right),(\mathrm{Na}-\mathrm{Cl})$ versus $\left(\mathrm{Ca}+\mathrm{Mg}-\mathrm{HCO}_{3}-\mathrm{SO}_{4}\right),(\mathrm{Ca}+\mathrm{Mg})$ versus $\mathrm{Cl}$ and $\mathrm{Na}$ / $\mathrm{Cl}$ versus $\mathrm{Cl}$, respectively, while Piper diagram was plotted using AquaChem V4 software package. Factor and cluster analyses were applied to interpret the geochemical data using SPSS 16 statistics software.

\section{Results and discussion}

The groundwater samples collected in different culture periods are listed in Table 2 showing the results of physicochemical parameters found in descriptive statistics such as maximum, minimum, mean and standard deviation. In culture-wise analysis, little higher $\mathrm{pH}$ value is observed in
PC period with the mean value of 8.51 and the values ranging from 8.11 to 8.85 . $\mathrm{pH}$ value ranges from 7.51 to 8.77 , 7.07 to $8.77,7.63$ to 8.35 and 7.37 to 8.77 with the mean value of 7.96, 7.95, 7.95 and 7.88 during SC, IASH, WC and IAWH, respectively. Culture-wise analysis shows that all the samples have $\mathrm{pH}$ values more than 7 , indicating alkaline nature of the samples, and it was controlled by the amount of dissolved $\mathrm{CO}_{2}$, carbonate and bicarbonate in groundwater (Senthilkumar et al. 2017). Culture-wise analysis shows that the higher concentration of EC values was noted during IAWH period with a mean value of $2180 \mu \mathrm{s} / \mathrm{cm}$ and the value ranges from 462 to $7425 \mu \mathrm{s} / \mathrm{cm}$. During IASH, SC, WC and PC periods, the value ranges from 376 to 6320,512 to 7350,705 to 4486 and 396 to $7360 \mu \mathrm{s} / \mathrm{cm}$ with the mean value of $2175 \mu \mathrm{s} / \mathrm{cm}, 2159 \mu \mathrm{s} / \mathrm{cm}, 1964 \mu \mathrm{s} / \mathrm{cm}$ and $1938 \mu \mathrm{s} /$ $\mathrm{cm}$, respectively. The spatial distribution map (Fig. 2) was drawn as per the classification used by Subramani et al. 2005, and the higher concentration was noted in the study area indicating effective leaching of ions into the groundwater system recharge (Singaraja et al. 2013). The unsuitable limit was observed in a specific location near to the creek of south-eastern and central-north, few parts near to the sea
Table 1 Classification as per culture periods

\begin{tabular}{lll}
\hline & Different culture periods & Month \\
\hline Culture period & Pre-culture (PC) & January, February \\
& Summer culture (SC) & March, April, May and June \\
& Immediately after summer harvest (IASH) & July, August \\
& Winter culture (WC) & September, October and November \\
& Immediately after winter harvest (IAWH) & December \\
\hline
\end{tabular}




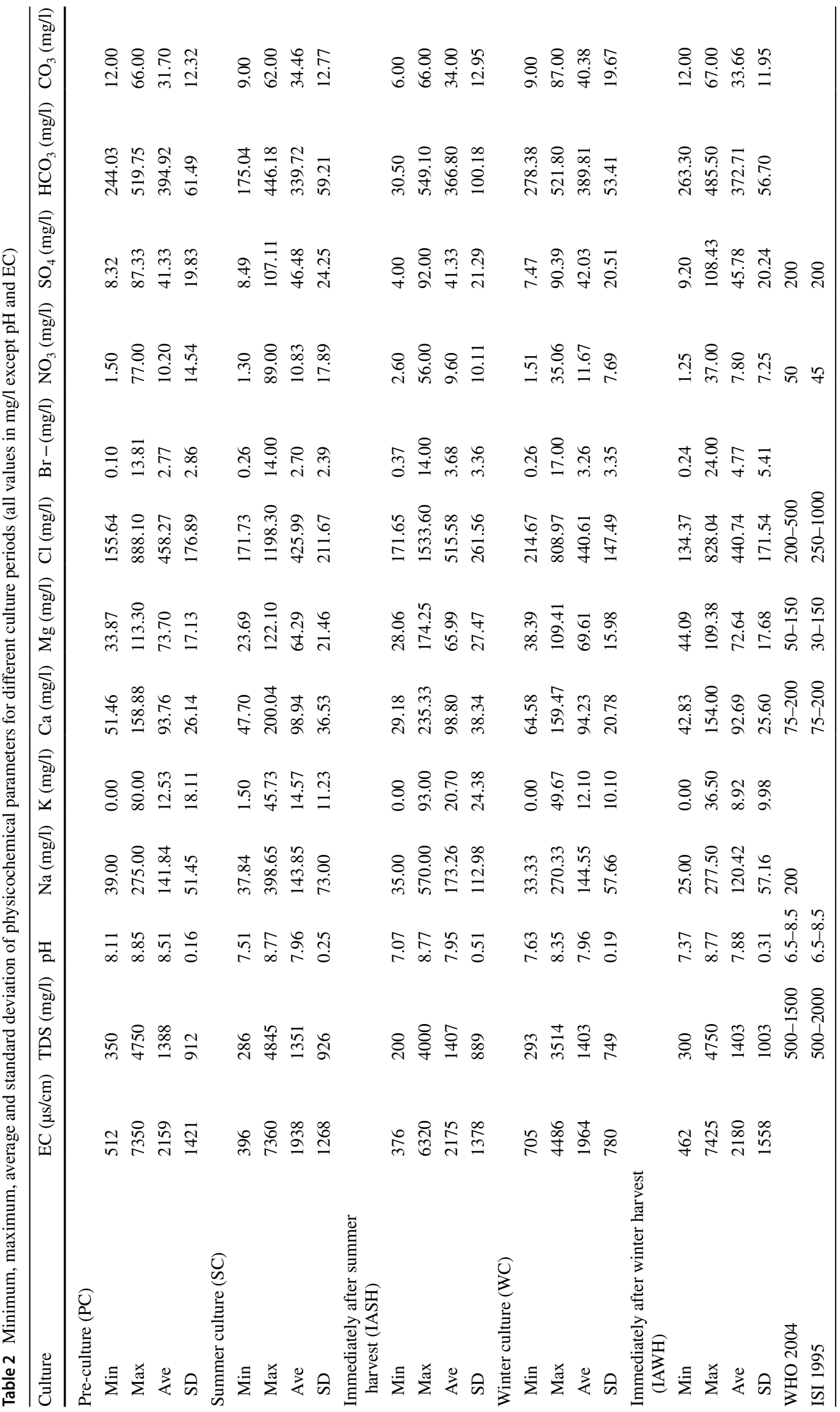




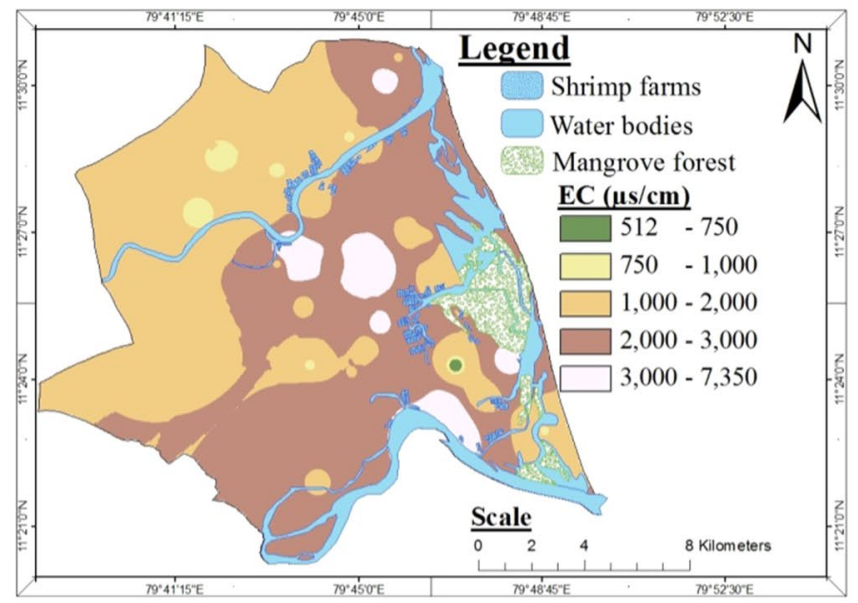

(a) $\mathrm{PC}$

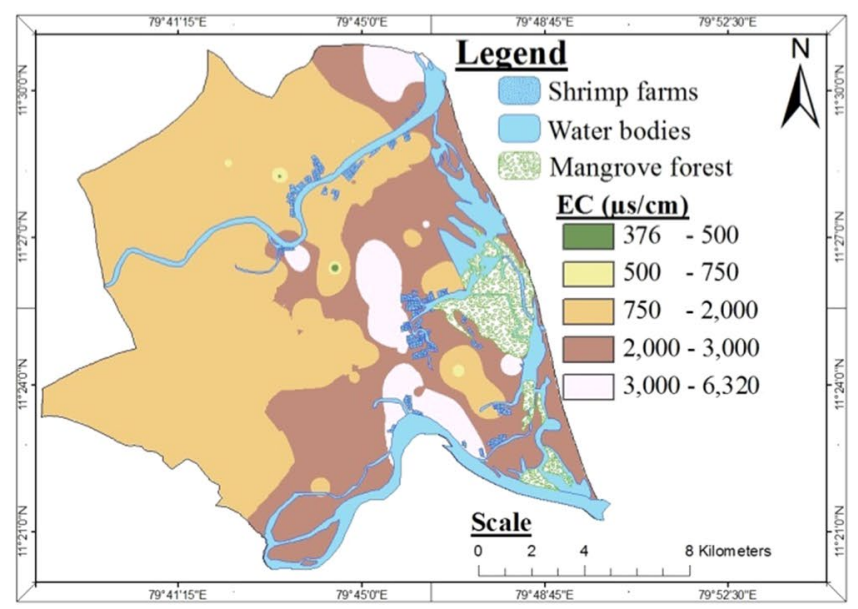

(c) IASH

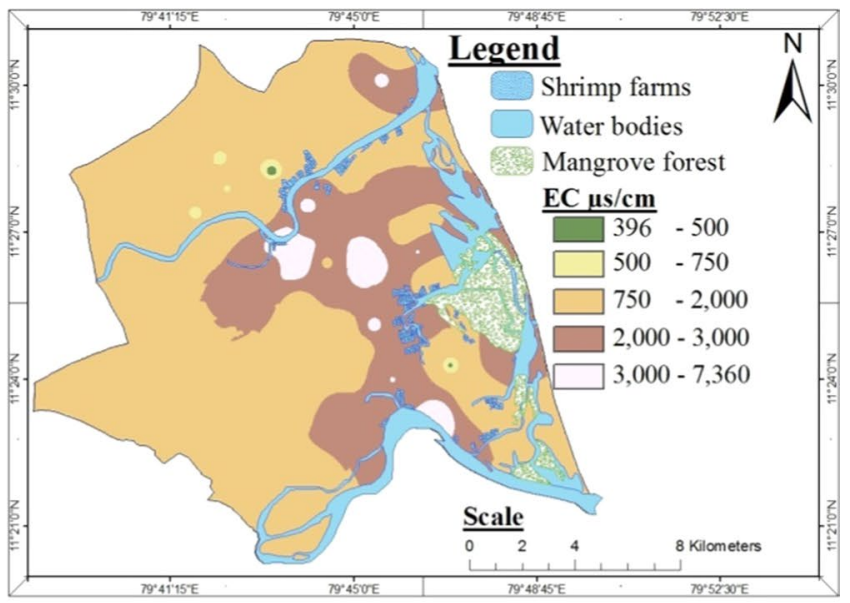

(b) $\mathrm{SC}$

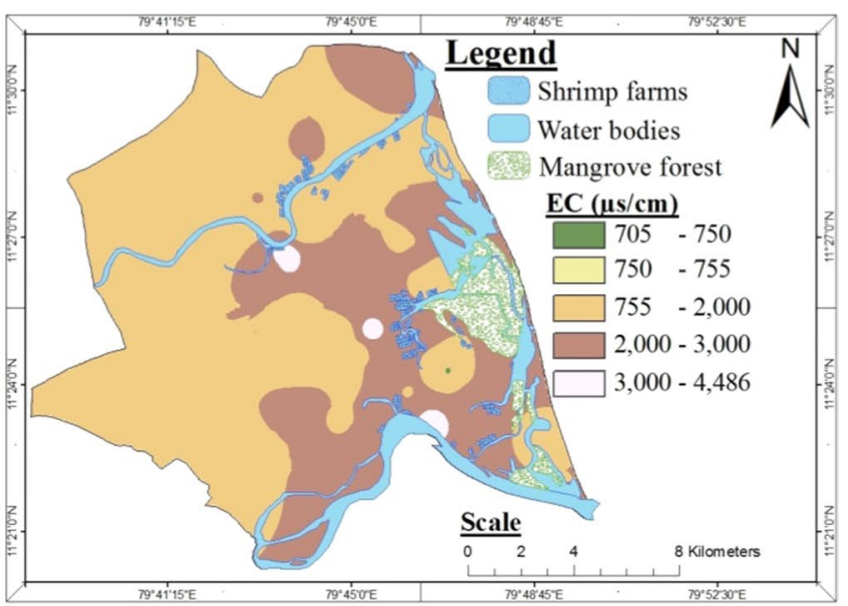

(d) WC

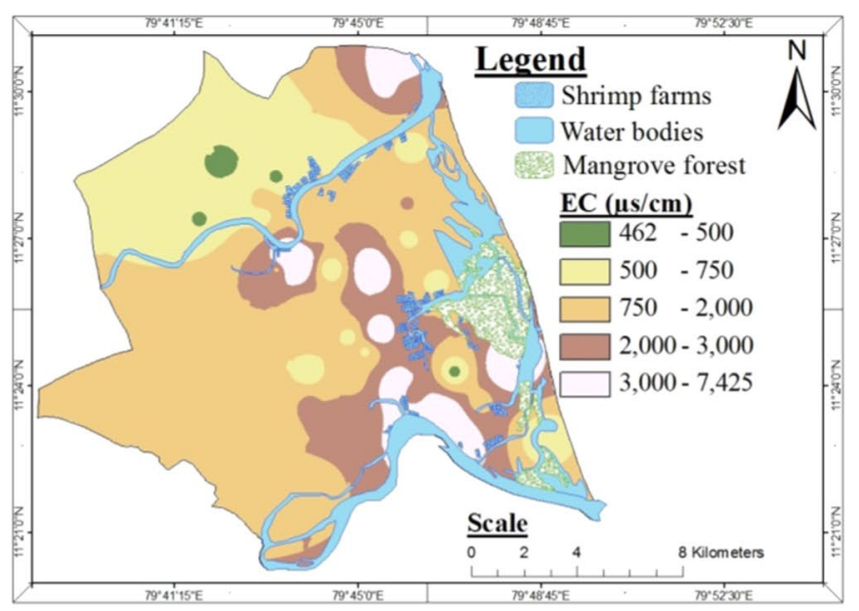

(e) IAWH

Fig. 2 Spatial distribution map for EC 


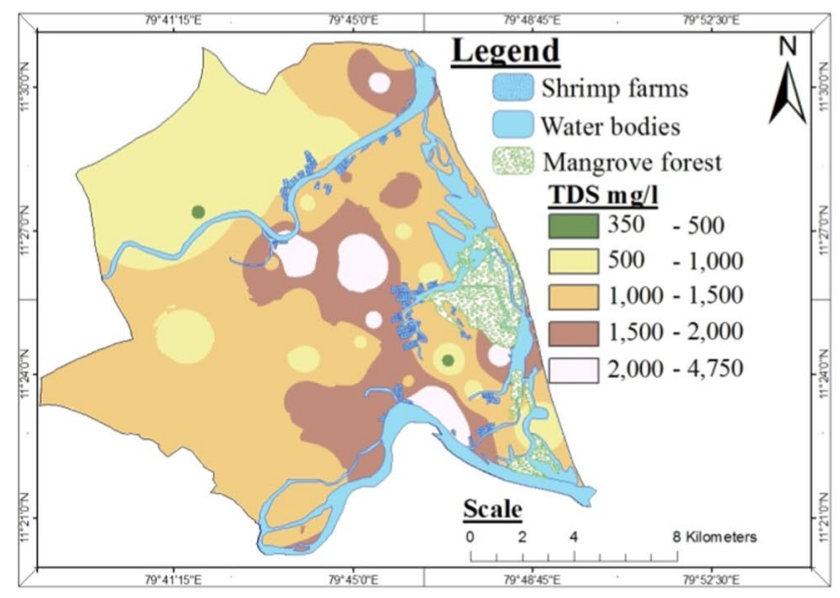

(a) $\mathrm{PC}$

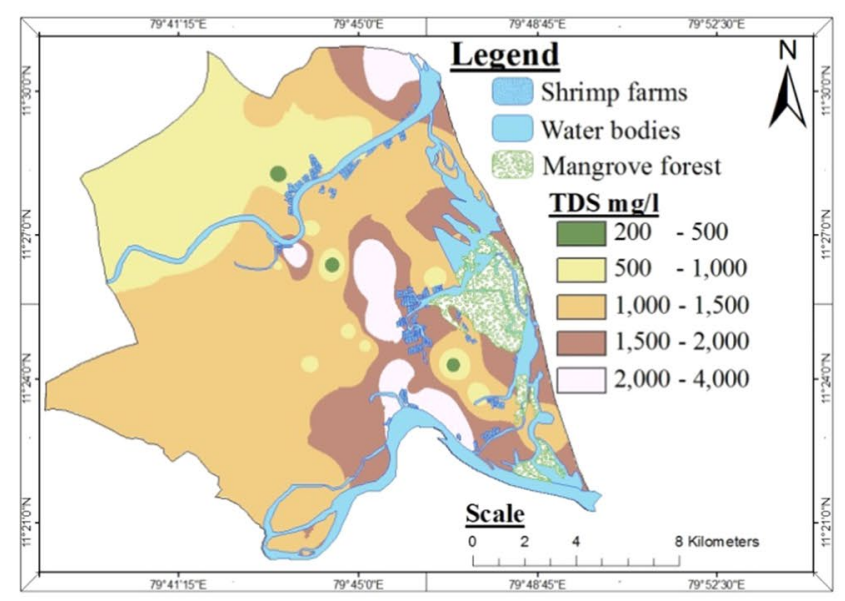

(c) IASH

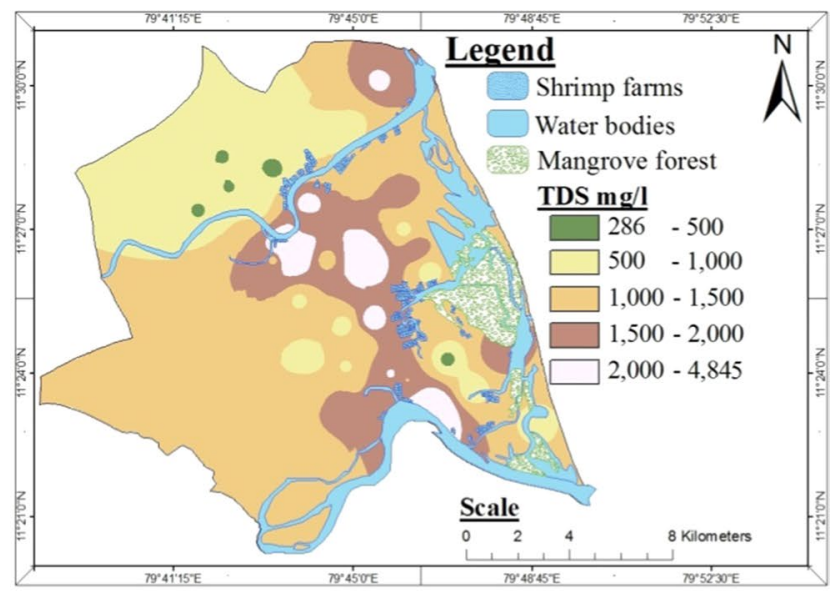

(b) $\mathrm{SC}$

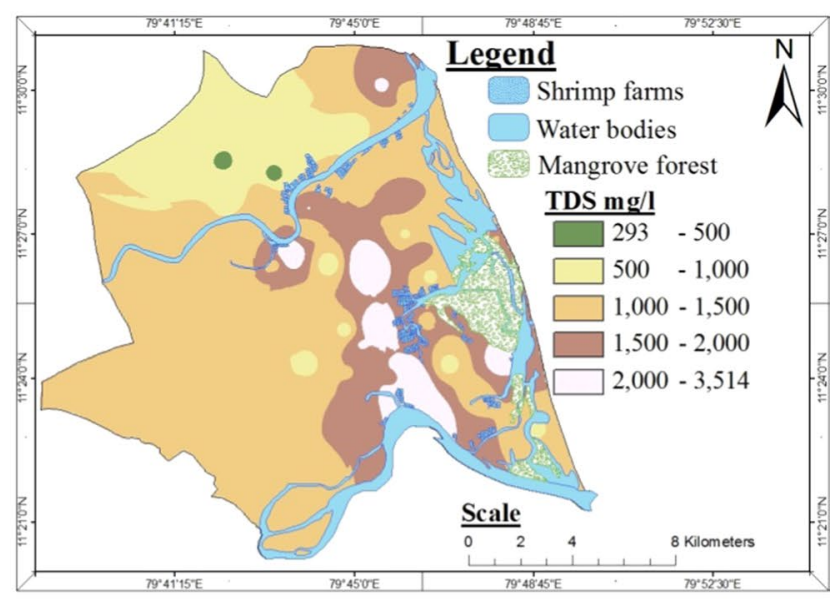

(d) WC

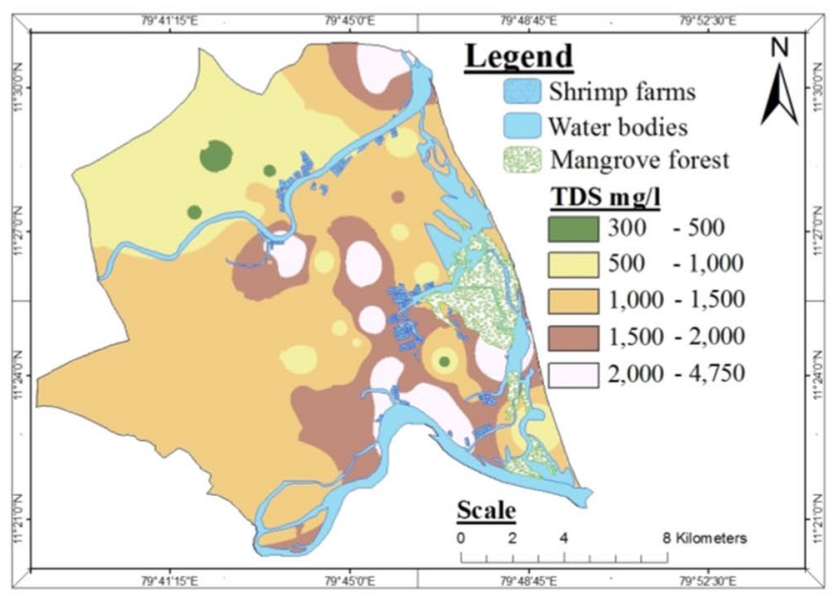

(e) IAWH

Fig. 3 Spatial distribution map for TDS 
Table 3 Characteristics of Chadha's classification for different culture periods
Fig. 4 Major facies representations in different culture periods

\begin{tabular}{|c|c|c|c|c|c|c|c|c|c|c|}
\hline \multirow[t]{2}{*}{ Groundwater types } & \multicolumn{2}{|c|}{$\begin{array}{l}\text { Samples } \\
\text { in the PC } \\
\text { category }\end{array}$} & \multicolumn{2}{|c|}{$\begin{array}{l}\text { Samples } \\
\text { in the SC } \\
\text { category }\end{array}$} & \multicolumn{2}{|c|}{$\begin{array}{l}\text { Samples in } \\
\text { the IASH } \\
\text { category }\end{array}$} & \multicolumn{2}{|c|}{$\begin{array}{l}\text { Samples in the WC } \\
\text { category }\end{array}$} & \multicolumn{2}{|c|}{$\begin{array}{l}\text { Samples in } \\
\text { the IAWH } \\
\text { category }\end{array}$} \\
\hline & $\begin{array}{l}\text { No. of } \\
\text { samples }\end{array}$ & $\%$ & $\begin{array}{l}\text { No. of } \\
\text { samples }\end{array}$ & $\%$ & $\begin{array}{l}\text { No. of } \\
\text { samples }\end{array}$ & $\%$ & No. of samples & $\%$ & $\begin{array}{l}\text { No. of } \\
\text { samples }\end{array}$ & $\%$ \\
\hline $\mathrm{Ca}-\mathrm{Mg}-\mathrm{Cl}$ type & 35 & 76 & 34 & 74 & 28 & 61 & 41 & 89 & 40 & 87 \\
\hline $\mathrm{Na}-\mathrm{Cl}$ type & 6 & 13 & 7 & 15 & 13 & 28 & 5 & 11 & 3 & 7 \\
\hline $\mathrm{Ca}-\mathrm{HCO}_{3}$ type & 4 & 9 & 3 & 7 & 2 & 4 & & & 2 & 4 \\
\hline $\mathrm{Ca}-\mathrm{Na}-\mathrm{HCO}_{3}$ type & 1 & 2 & 1 & 2 & 2 & 4 & & & 1 & 2 \\
\hline
\end{tabular}

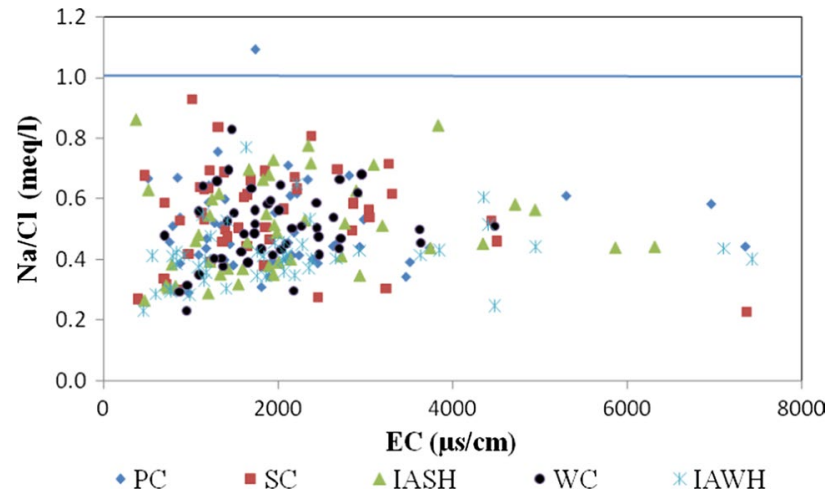

Fig. $5 \mathrm{Na} / \mathrm{Cl}$ versus $\mathrm{EC}$ relationship of north-eastern side and central-eastern parts of the study area. It could also be observed that shrimp farming is less in that area.

The culture-wise TDS concentration in groundwater indicates that high values were observed during IASH season, and the value ranges from 200 to $4000 \mathrm{mg} / \mathrm{l}$ with the mean value of $1407 \mathrm{mg} / \mathrm{l}$. During IAWH, WC, PC and SC, the values range from 462 to $7425 \mathrm{mg} / \mathrm{l}, 293$ to $3514 \mathrm{mg} / \mathrm{l}, 350$ to $4750 \mathrm{mg} / \mathrm{l}$ and 286 to $4845 \mathrm{mg} / \mathrm{l}$ with the mean value of $1403 \mathrm{mg} / \mathrm{l}, 1403 \mathrm{mg} / \mathrm{l}, 1388 \mathrm{mg} / \mathrm{l}$ and $1351 \mathrm{mg} / \mathrm{l}$, respectively. According to WHO 2004 and ISI 1983, TDS above the $2000 \mathrm{mg} / \mathrm{l}$ is considered as the unsuitable, and the presence of TDS above this limit in groundwater would cause 


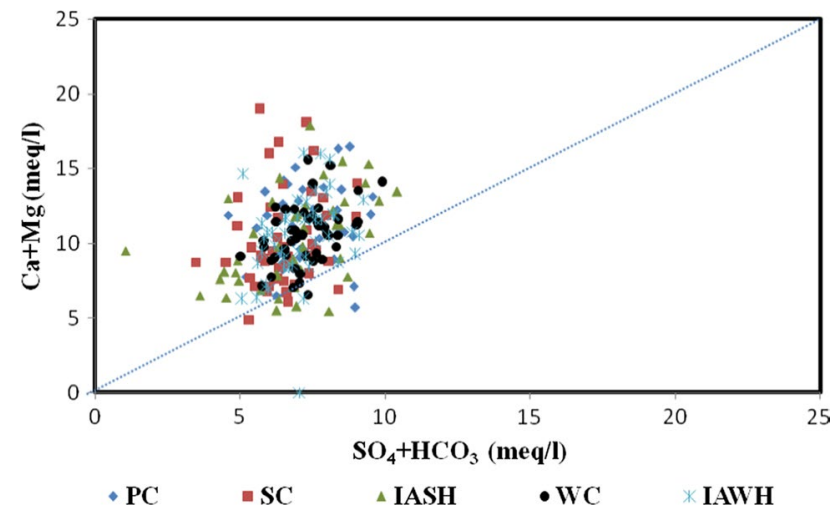

Fig. $6 \mathrm{Ca}+\mathrm{Mg}$ versus $\mathrm{SO}_{4}+\mathrm{HCO}_{3}$ ionic relationship
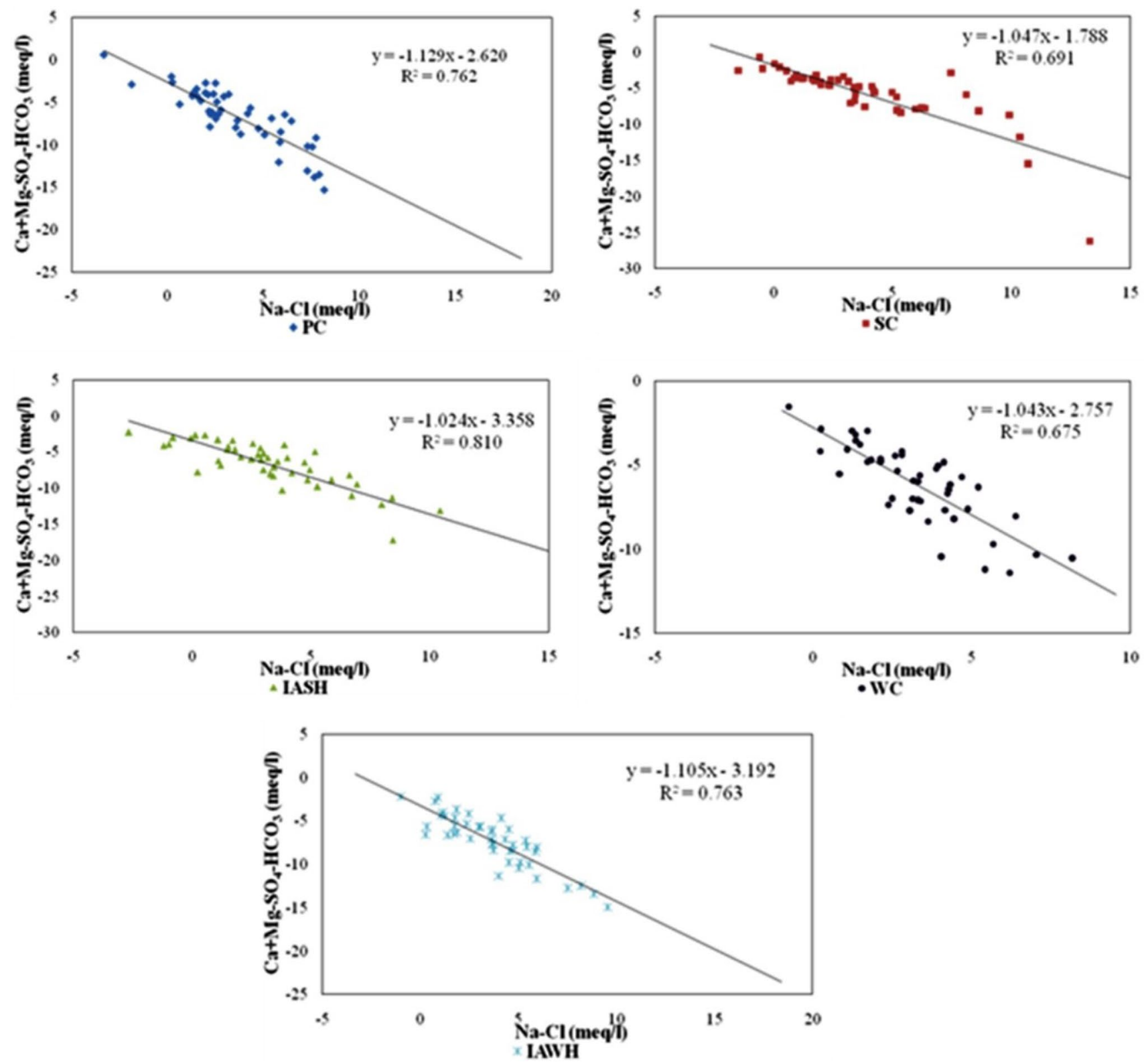

Fig. $7 \mathrm{Na}-\mathrm{Cl}$ versus $\mathrm{Ca}+\mathrm{Mg}-\mathrm{HCO}_{3}-\mathrm{SO}_{4}$ ionic relationship

an undesirable taste and gastrointestinal irritation (Shigut et al. 2017). The spatial distribution (Fig. 3) clearly shows that there is no significant difference between different culture periods with respect to the TDS concentration of the groundwater quality. Also, it could be noted that the high content of TDS may be due to improper sewage disposal, lesser $\mathrm{pH}$ with higher mineral dissolution and seawater intrusion (Singaraja et al. 2014). The abundance of major ions in the groundwater was in the order of $\mathrm{Na}>\mathrm{Ca}>\mathrm{Mg}>\mathrm{K}$ for cations and for that of anions $\mathrm{Cl}>\mathrm{HCO}_{3}>\mathrm{SO}_{4}>\mathrm{CO}_{3}$ $>\mathrm{NO}_{3}>\mathrm{Br}$ during different culture periods following the same trends. 


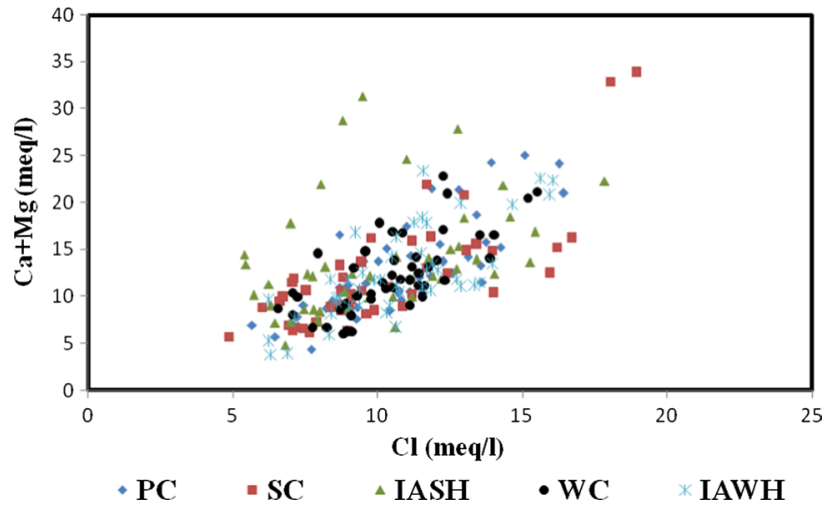

Fig. $8(\mathrm{Ca}+\mathrm{Mg})$ versus $\mathrm{Cl}$ ionic relationship

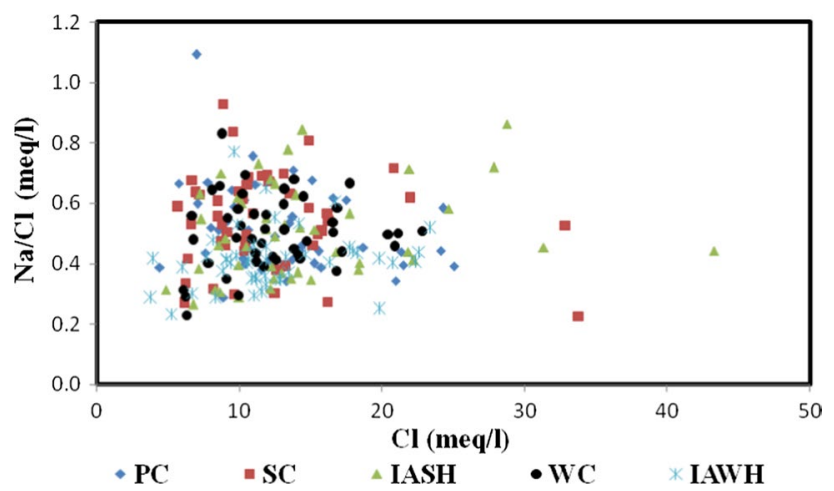

Fig. $9 \mathrm{Na} / \mathrm{Cl}$ versus $\mathrm{Cl}$ ionic relationship

\section{Hydrogeochemical trends}

The Piper plot in the hydrogeochemical facies is sufficient and elaborated studies in groundwater and it is the fundamental interpretation for understanding chemical nature of water quality (Subramani et al. 2005; Senthilkumar et al. 2017). The results of Piper plot (Table 3) show that most of the groundwater samples during different culture periods fall in the field of mixed $\mathrm{Ca}-\mathrm{Mg}-\mathrm{Cl}$ type of water (Fig. 4). The plot shows that during PC period, groundwater quality is mixed $\mathrm{Ca}-\mathrm{Mg}-\mathrm{Cl}$ type with $76 \%(n=35)$ of samples falling under this category. It is then followed by $\mathrm{Na}-\mathrm{Cl}$ type with $13 \%(n=6), \mathrm{Ca}-\mathrm{HCO}_{3}$ type with $9 \%$ $(n=4)$ and $\mathrm{Ca}-\mathrm{Na}-\mathrm{HCO}_{3}$ type with $2 \%(n=1)$, respectively. Similarly during SC period, the groundwater quality shows mixed $\mathrm{Ca}-\mathrm{Mg}-\mathrm{Cl}$ type with $74 \%(n=34)$, $\mathrm{Na}-\mathrm{Cl}$ type with $15 \%(n=7), \mathrm{Ca}-\mathrm{HCO}_{3}$ type with $7 \%(n=1)$ and mixed $\mathrm{Ca}-\mathrm{Na}-\mathrm{HCO}_{3}$ with $2 \%(n=1)$, respectively. During IASH period, the analysis shows mixed $\mathrm{Ca}-\mathrm{Mg}-\mathrm{Cl}$ type with $61 \%$ ( $n=18$ ) of samples falling under this category, followed by $\mathrm{Na}-\mathrm{Cl}$ type with $28 \%(n=13)$. The remaining samples were equally distributed as mixed $\mathrm{Ca}-\mathrm{Na}-\mathrm{HCO}_{3}$ type with $4 \%(n=2)$ and $\mathrm{Ca}-\mathrm{HCO}_{3}$ type with $4 \%(\mathrm{n}=2)$. During WC period, the result shows that the groundwater samples fall under mixed $\mathrm{Ca}-\mathrm{Mg}-\mathrm{Cl}$ type with $89 \%(n=41)$, followed by $\mathrm{Na}-\mathrm{Cl}$ type with $11 \%(n=5)$. During IAWH period, the sample represented mixed $\mathrm{Ca}-\mathrm{Mg}-\mathrm{Cl}$ type with $87 \%$ $(n=40)$, followed by $\mathrm{Na}-\mathrm{Cl}$ type with $7 \%\left(n=1, \mathrm{Ca}-\mathrm{HCO}_{3}\right.$ with $4 \%(n=1)$ and $\mathrm{Ca}-\mathrm{Na}-\mathrm{HCO}_{3}$ with $2 \%(n=1)$. The Piper plot revealed that there is no significant change in the hydrogeochemical facies during different culture periods. The analysis of ionic distribution in the study area shows that alkaline earths ( $\mathrm{Ca}$ and $\mathrm{Mg}$ ) significantly exceed the alkalis ( $\mathrm{Na}$ and $\mathrm{K})$ so as the strong acids $\left(\mathrm{Cl}\right.$ and $\left.\mathrm{SO}_{4}\right)$ exceed the weak acids $\left(\mathrm{HCO}_{3}\right.$ and $\left.\mathrm{CO}_{3}\right)$. Moreover, Piper diagram depicts that strong acids are more dominant, explaining that chemical composition of the groundwater is controlled by ion exchange reactions.
Fig. 10 Chadha's geochemical process

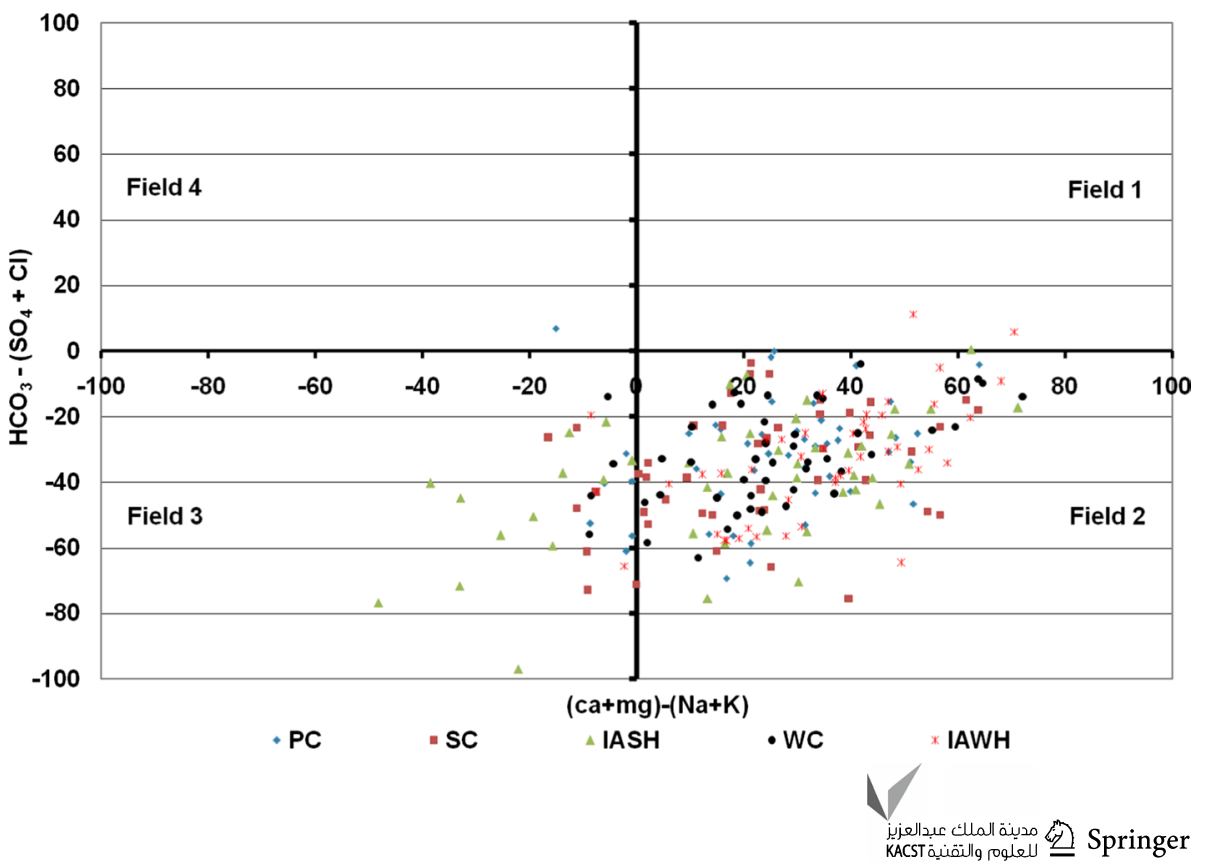




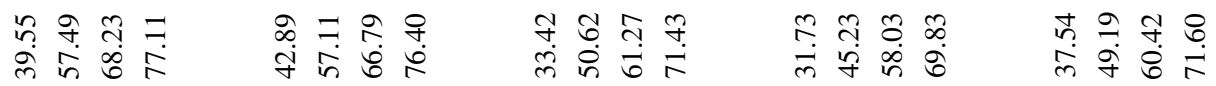

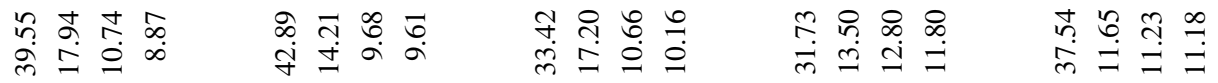

苛

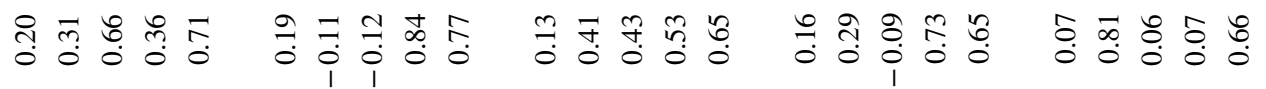

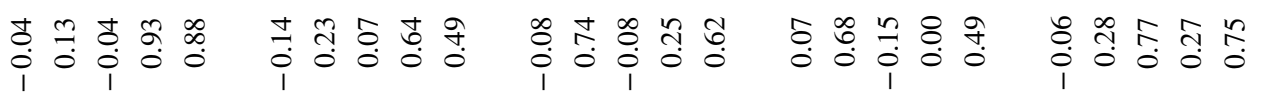

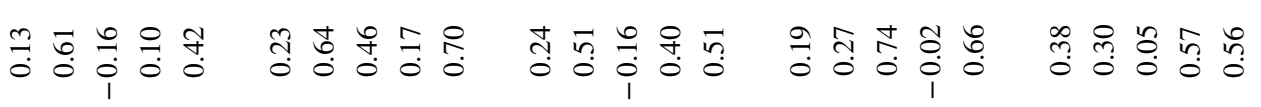

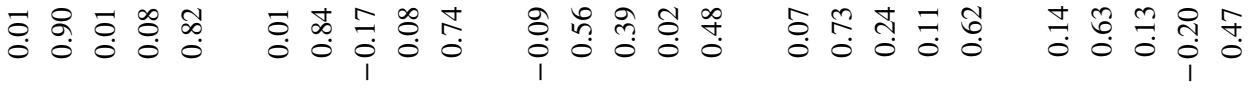

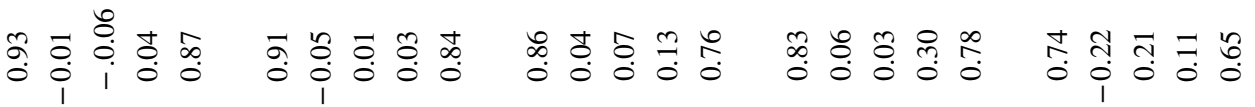

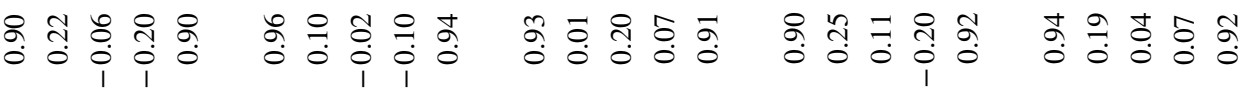

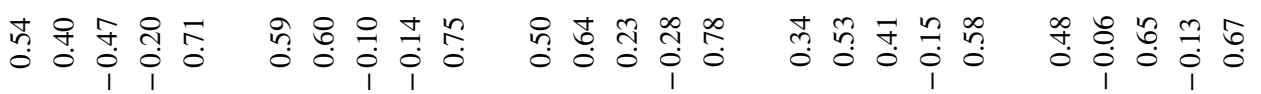

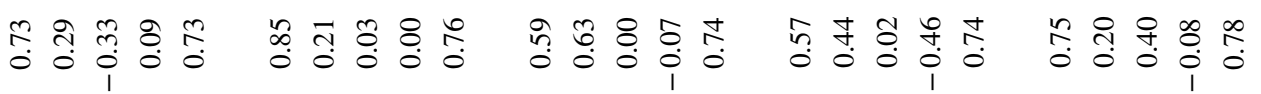

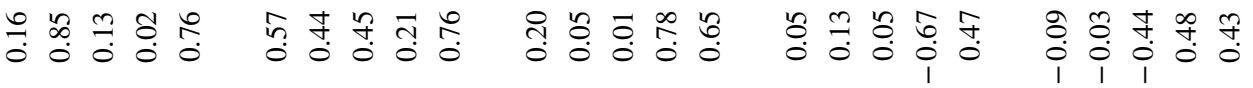

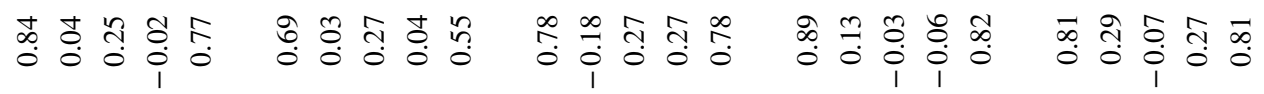

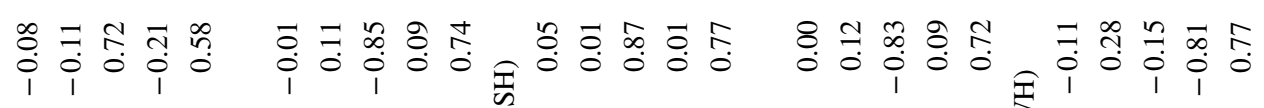

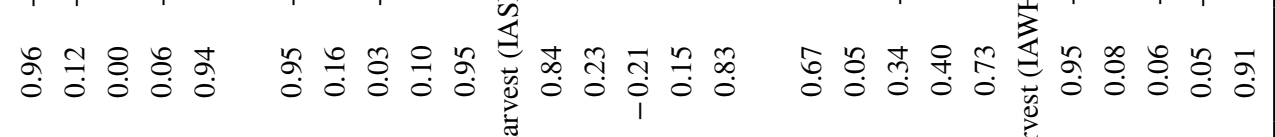

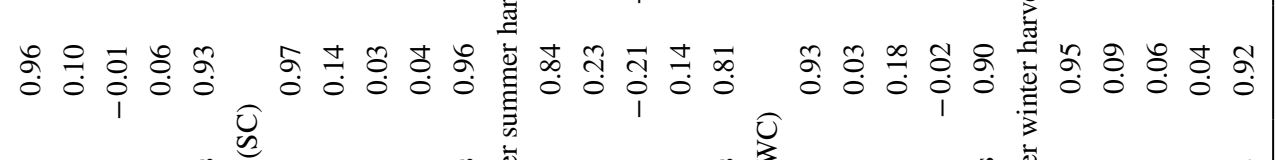




\section{$\mathrm{Na} / \mathrm{Cl}$ versus $\mathrm{EC}$ plot}

The $\mathrm{Na} / \mathrm{Cl}$ versus EC plot (Fig. 5) clearly indicates that the ratio of $\mathrm{Na} / \mathrm{Cl}$ increases with a decreasing $\mathrm{EC}$ value during different culture periods. A high sodium chloride ratio was observed at low EC value $(<2000)$ during the winter season and pre-culture periods. The $\mathrm{Na} / \mathrm{Cl}$ molar ratio should be approximately equal to one, whereas a ratio greater than one is typically interpreted as Na released from a silicate weathering reaction (Meybeck 1987). Samples having a $\mathrm{Na} / \mathrm{Cl}$ ratio greater than one indicate excess sodium, which might have come from silicate weathering or seawater intrusion. If silicate weathering is a probable source of sodium, the water samples would have $\mathrm{HCO}_{3}$ as the most abundant anion (Rogers 1989). This is because of the reaction of the feldspar minerals with the carbonic acid in the presence of water, which releases $\mathrm{HCO}_{3} \cdot \mathrm{HCO}_{3}$ is not the dominant anion in groundwater (Elango et al. 2003). Culture-wise analysis shows that only one sample $(>1)$ was observed during PC period, and the values range from 0.29 to 1.09 (meq/l) with the mean value of $0.51 \mathrm{meq} / \mathrm{l}$. The remaining samples in different culture periods $(<1)$ indicate the possibility of some other chemical processes, such as reverse ion exchange. During SC, IASH, WC and IAWH, the values range from 0.23 to 0.93 (meq/l), 0.26 to 0.86 (meq/l), 0.23 to $0.83(\mathrm{meq} / \mathrm{l}), 0.23$ to $0.77(\mathrm{meq} / \mathrm{l})$ with the mean value of 0.54 (meq/l), 0.50 (meq/l), $0.50(\mathrm{meq} / \mathrm{l})$ and 0.41 (meq/l), respectively.

\section{Reverse ion exchange}

Reverse ion exchange is one of the important processes responsible for the concentration of ions in groundwater. The influence of saline water bodies contributes to the parameters such as reverse ion exchange and high salinity (Seshadri et al. 2013). Ion exchange tends to shift the points to the right due to an excess of $\mathrm{SO}_{4}+\mathrm{HCO}_{3}$ (Fisher and Mulican 1997). If reverse ion exchange is the process, it will shift the points to the left due to a large excess of $\mathrm{Ca}+\mathrm{Mg}$ over $\mathrm{SO}_{4}+\mathrm{HCO}_{3}$, which can be explained by the following reaction:

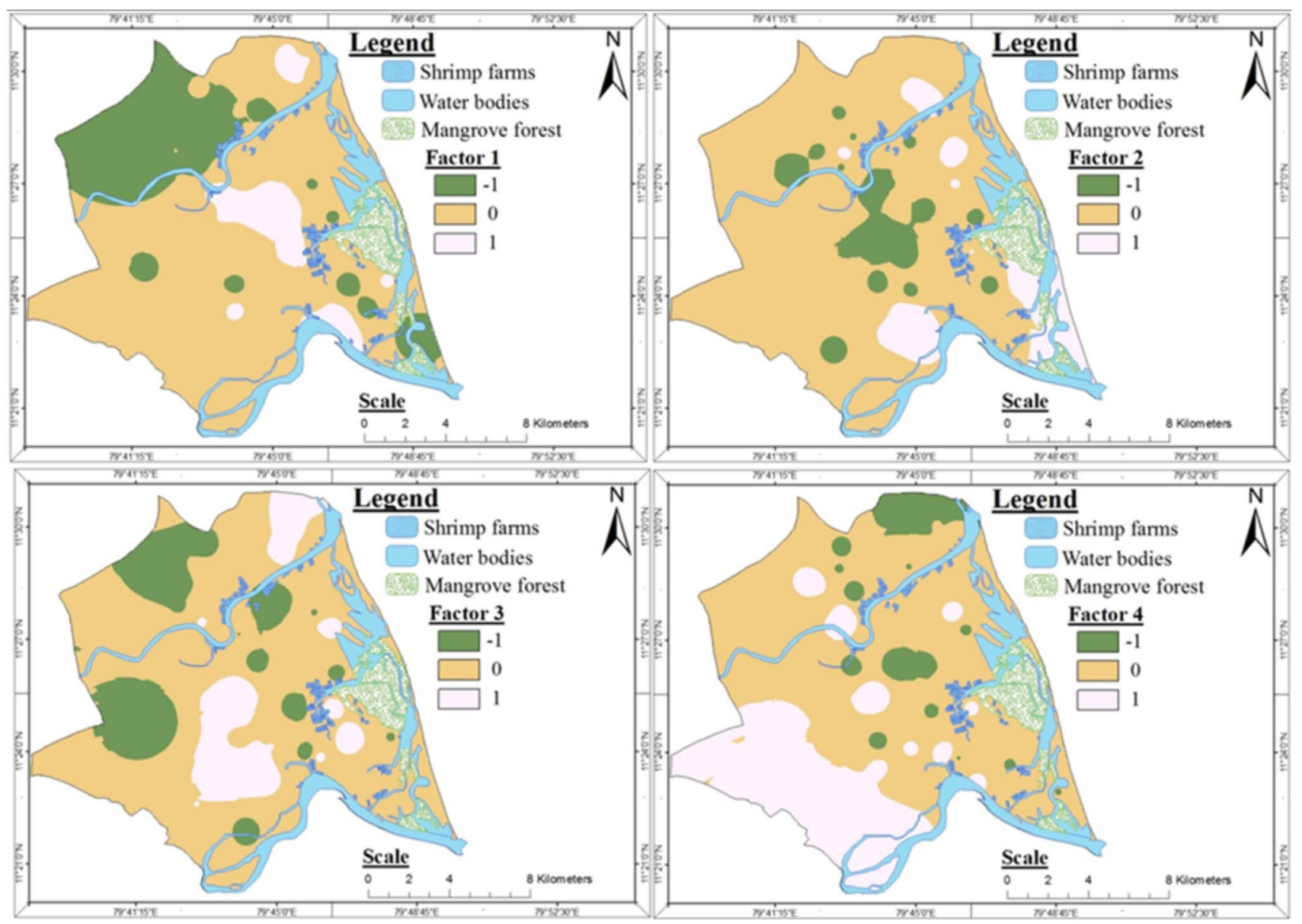

Fig. 11 Spatial distribution map of factor score for PC period 


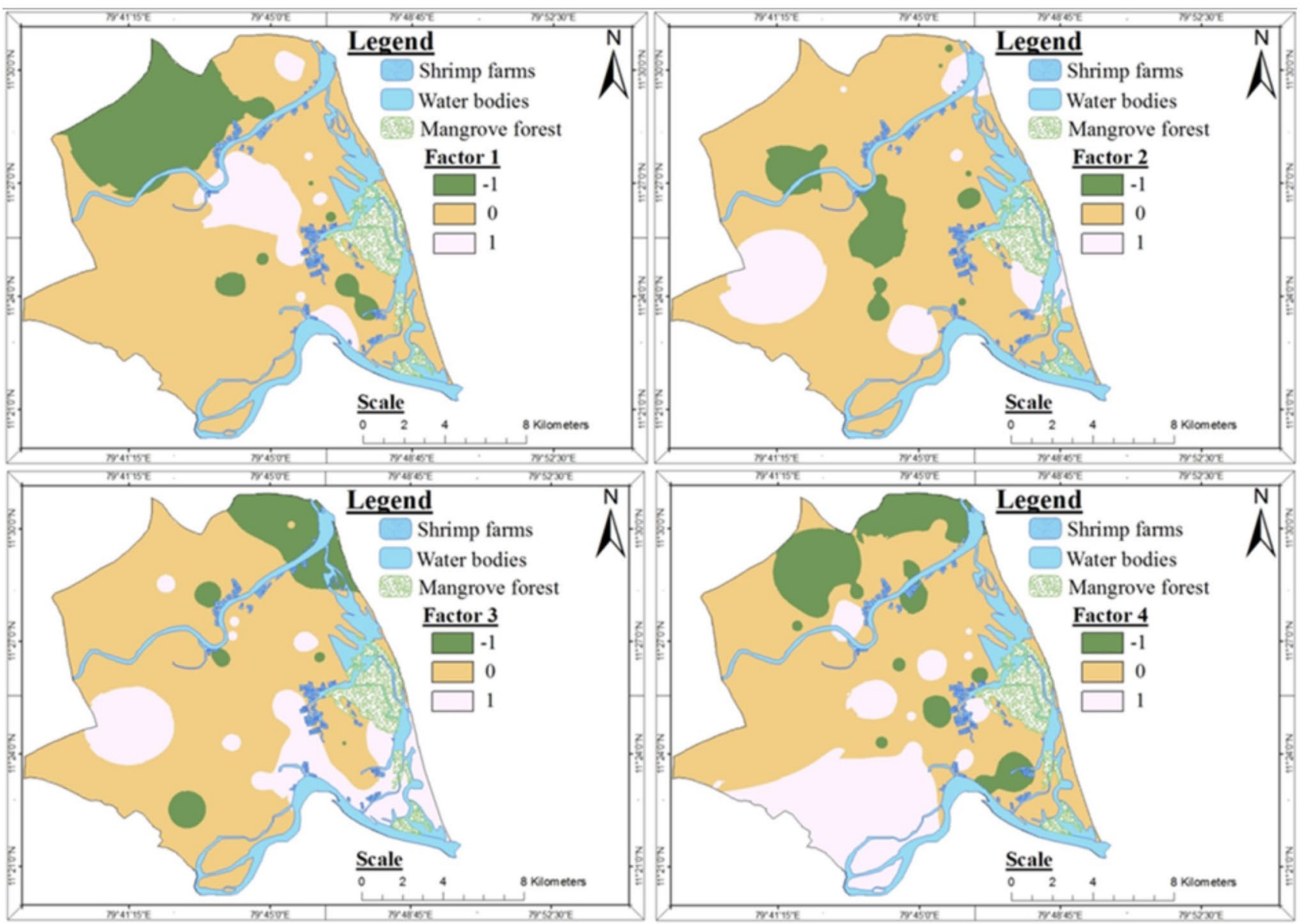

Fig. 12 Spatial distribution map of factor score for SC period

$$
\mathrm{Na}^{+}+\mathrm{Ca}(\mathrm{Mg}) \text { clay } \ll \mathrm{Na}-\text { clay }+\mathrm{Ca}^{2+}\left(\mathrm{Mg}^{2+}\right)
$$

In $\mathrm{Ca}+\mathrm{Mg}$ versus $\mathrm{SO}_{4}+\mathrm{HCO}_{3}$ scatter diagram, the points falling along the equiline $\left(\mathrm{Ca}+\mathrm{Mg}=\mathrm{SO}_{4}+\mathrm{HCO}_{3}\right)$ suggest that these ions have resulted from weathering of carbonates and sulphate minerals (Datta et al. 1996) and may be due to dissolutions of calcite, dolomite and gypsum, which are the dominant reactions in a system (Rajmohan and Elango 2001). Moreover, if the $\mathrm{Ca}$ and $\mathrm{Mg}$ solely originated from carbonate and silicate weathering, these should be balanced by the alkalinity alone. The result in the present study (Fig. 6) shows that most of the groundwater samples from different culture periods were clustered around and above the 1:1 line. Culture-wise analysis shows that the percentage of samples present above the 1:1 lines was $95.65 \%, 91.30 \%$, $89.13 \%, 97.83 \%$ and $97.83 \%$ for PC, SC, IASH, WC and IAWH, respectively. It indicates that all samples during different culture periods represented the reverse ion exchange process.

The plot of $\mathrm{Na}-\mathrm{Cl}$ versus $\mathrm{Ca}+\mathrm{Mg}-\mathrm{HCO}_{3}-\mathrm{SO}_{4}$ also supports the hypothesized reverse ion exchange process. If ion exchange is the dominant process in the present system, the water should form a line with a slope of -1 . From Fig. 7 , it can be observed that during PC, SC, IASH, WC and IAWH the slope values are $0.76,0.69,0.81,0.68$ and 0.76 , respectively. This confirms that $\mathrm{Ca}, \mathrm{Mg}$ and $\mathrm{Na}$ concentrations are interrelated through reverse ion exchange. An excess of calcium and magnesium in the groundwater of sedimentary formations may be due to the exchange of sodium in the water by calcium and magnesium in clay material. The plot of $(\mathrm{Ca}+\mathrm{Mg})$ versus $\mathrm{Cl}$ (Fig. 8) indicates that $\mathrm{Ca}$ and $\mathrm{Mg}$ increase with increasing salinity in the different culture periods. The plots of $\mathrm{Na} / \mathrm{Cl}$ versus $\mathrm{Cl}$ (Fig. 9) also clearly indicate that salinity increases with the decrease in $\mathrm{Na} / \mathrm{Cl}$ during all culture periods. It indicates the increase in $\mathrm{Ca}+\mathrm{Mg}$ and decrease in $\mathrm{Na} / \mathrm{Cl}$, which may be due to reverse ion exchange in the clay/weathered layer.

\section{Chadha's classification}

According to Vandenbohede et al. 2010, the hydrogeochemical processes for a coastal aquifer occurring in the 


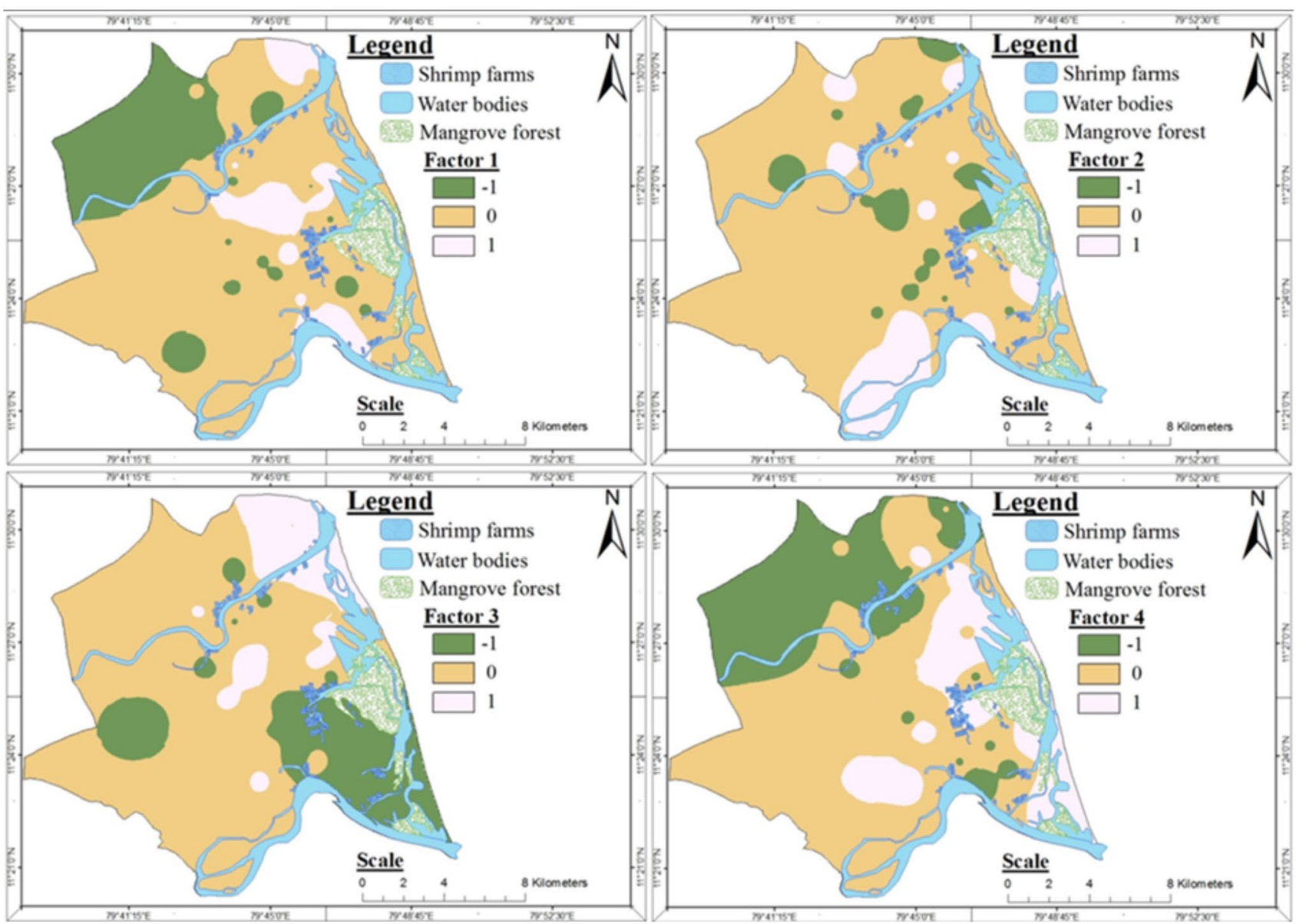

Fig. 13 Spatial distribution map of factor score for IASH period

study area clearly bring out the Chadha's classification. The groundwater quality data are converted to percentage reaction values (milliequivalent percentages) and expressed as the difference between the alkaline earths $(\mathrm{Ca}+\mathrm{Mg})$ and alkali metals $(\mathrm{Na}+\mathrm{K})$ for cations, and the difference between the weak acidic anions $\left(\mathrm{HCO}_{3}+\mathrm{CO}_{3}\right)$ and strong acidic anions $\left(\mathrm{Cl}+\mathrm{SO}_{4}\right)$ (Karmegam et al. 2010). The hydrogeochemical processes suggested by Chadha's classification are indicated in each of the four quadrants of the graph (Fig. 10). These are broadly summarized as recharging water $\left(\mathrm{Ca}-\mathrm{HCO}_{3}\right)$, reverse ion exchange water $(\mathrm{Ca}-\mathrm{Mg}-\mathrm{Cl})$, seawater/end-member water $(\mathrm{Na}-\mathrm{Cl})$ and base ion exchange water $\left(\mathrm{Na}-\mathrm{HCO}_{3}\right)$. Field-1 represents the recharging water, and it indicates the formation of geochemically mobile calcium as a result of dissolved carbonate. Only few samples were observed in this field during different culture periods. Field- 2 represents the reverse ion exchange process. This indicates that the groundwater representing $\mathrm{Ca}+\mathrm{Mg}$ is in excess of $\mathrm{Na}+\mathrm{K}$ due to reverse base exchange reactions of
$\mathrm{Ca}+\mathrm{Mg}$ in solution and subsequent adsorption of $\mathrm{Na}$ onto mineral surfaces. It could be seen from the plot that field 2 was the predominate feature in the study area during different culture-wise analyses, implying that the groundwater quality is dictated by the reverse ion exchange process rather than the shrimp culture. Field-3 represents $\mathrm{Na}-\mathrm{Cl}$ type, which indicates that the groundwater water is typical of a coastal aquifer wherein salinity is expected in the groundwater. It could be seen that less than $20 \%$ of groundwater sample fall in this field during different culture periods. Field-4 represents waters belonging to $\mathrm{Na}-\mathrm{HCO}_{3}$ type. Only one sample falls in this field, and it clearly indicates that base ion exchange was not the preferred process for the groundwater in the study area.

\section{Factor analysis}

As per Mor et al. 2006, the factor loading is classified into three categories in which a high loading was defined 


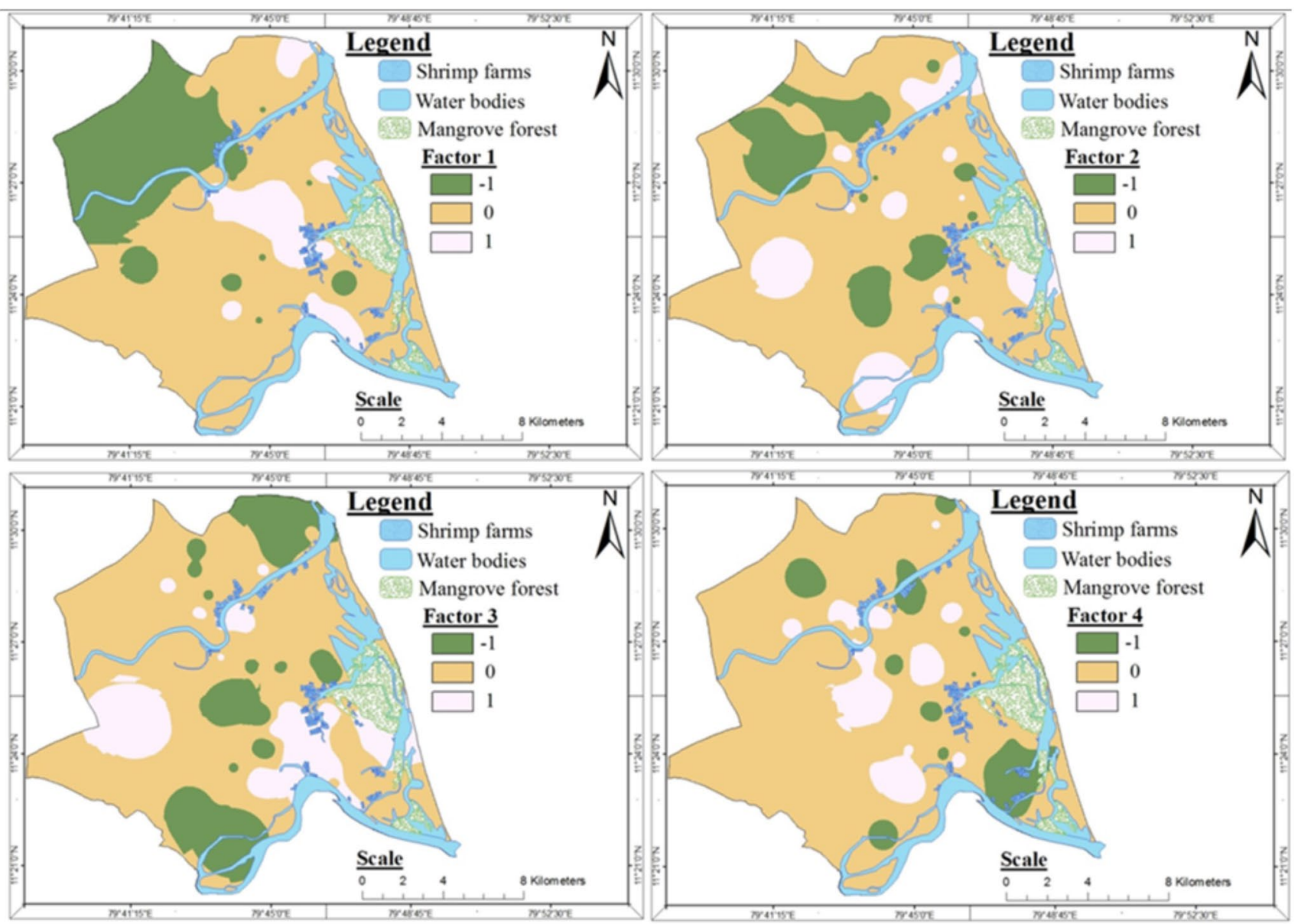

Fig. 14 Spatial distribution map of factor score for WC period

as greater than 0.75 , moderate loading was defined as $0.40-0.75$ and loading of less than 0.4 was considered insignificant. Factor score which gives values ' 0 ' represents average impact, ' -1 ' scores reflect areas essentially unaffected by that particular factors and ' +1 ' scores reflect the area's most affected (Giridharan et al. 2009). A total culture-wise analysis (Table 4) shows that four factors were identified which control the groundwater quality. During PC period (Fig. 11), factor 1 is influenced by $\mathrm{Na}, \mathrm{Cl}, \mathrm{Br}, \mathrm{EC}$ and TDS with $39.5 \%$ of variance indicating the intrusion of seawater into the aquifer system, which increases the concentrations of these ions (Prasanna et al. 2011), and the areal distribution map shows that the positive values are observed in the north-eastern, south-eastern and central-eastern sides of the study area and in that, shrimp farm area is very less $(0.20$ $\mathrm{km}^{2}$ ). Factor 2, which accounts for approximately $17.9 \%$ of variance, has a high loading of $\mathrm{K}$ and $\mathrm{NO}_{3}$ indicating the anthropogenic impact from the agricultural practices like fertilizers (Vengosh et al. 2002). The spatial distribution map of factor 2 represented that the positive loading is observed along south-eastern, south-western, north-eastern and central-eastern sides of the study area. Factor 3, which explains $10.7 \%$ of variance, has moderate loading of $\mathrm{pH}$ and $\mathrm{CO}_{3}$, and the spatial map represents the positive loading in north-eastern, central and central-eastern of the study area. Factor 4 is represented by $\mathrm{HCO}_{3}$, which account for $8.8 \%$ indicating the natural water recharge and rock-water interaction. The areal distribution map shows a positive loading in entire south-western side of the study area. In SC period (Fig. 12), factor 1, which explains $42.8 \%$ of variance, has a high loading of the ions such as $\mathrm{Ca}, \mathrm{Cl}, \mathrm{Br}, \mathrm{EC}$ and TDS, indicating leaching of secondary salts, and the spatial distribution shows the similar position of PC period. Factor 2 enriched with the $\mathrm{NO}_{3}$ with $14.2 \%$ of variance indicates the anthropogenic impact from the leaching of landfills (Ghabayen et al. 2006). Some of the wells in the northeastern, south-eastern, south and western sides are found to exhibit highly significant factor scores. Factor 3 with a variance of $9.6 \%$ represents the high loading in negative value of $\mathrm{pH}$, and the factor score spatial distribution map shows that the positive loading is found in the western and southeastern sides of the study area. Factor 4 is influenced by $\mathrm{CO}_{3}$ 


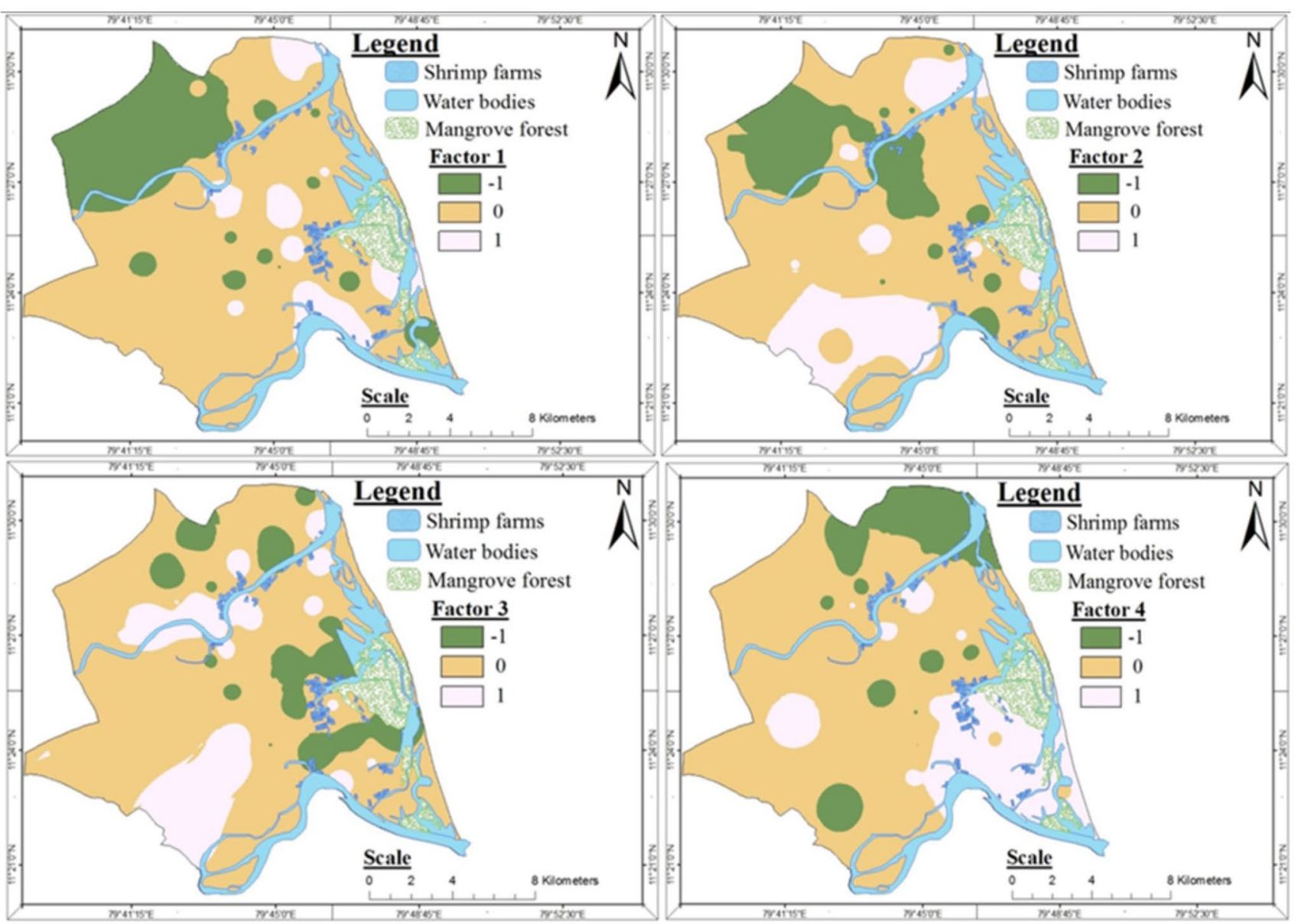

Fig. 15 Spatial distribution map of factor score for IAWH period

with $9.6 \%$ of variance, and the areal distribution map shows that the positive score is observed along the south-western side of the study area.

Factor 1 during IASH period (Fig. 13) explains 33.4\% of the variance, and it has high loading of $\mathrm{Na}, \mathrm{Cl}, \mathrm{Br}, \mathrm{EC}$ and TDS. The spatial distribution map shows that high positive factor scores are observed in north-eastern, southeastern and central parts of the study area with $0.28 \mathrm{~km}^{2}$ of shrimp farming area which is apparently unaffected by shrimp farming activities. There is no high loading observed in factor 2 , and the areal map suggests that the wells in the south-western, south-eastern, north-eastern, northern and central parts show high positive scores. Factor 3 is represented by $\mathrm{pH}$ with $10.6 \%$ of variance showing the dominance of the base ion exchange, and the factor score distribution map implies that positive values are observed in north-eastern and central parts of the study area. Factor 4 , which explains $10.1 \%$ of variance, has high loading of $\mathrm{K}$ indicating the anthropogenic impact, and high significant scores are observed in eastern and central parts of the study area. In WC period (Fig. 14), factor 1 with a variance of $4.1 \%$ represents the domination of $\mathrm{Na}, \mathrm{Cl}, \mathrm{Br}$ and $\mathrm{EC}$. The areal distribution map shows that wells located in the central-eastern, north-eastern and south-eastern sides are dominated by the positive factor scores with shrimp farming area of $0.79 \mathrm{~km}^{2}$. It has been observed that no high loading is being carried out in the factor 2 and factor 3 . However, the areal distribution map of factor 2 shows that the positive value is noted in northeastern, south-eastern, south-western, western and central parts of the study area. In factor 3 , dominant positive value is represented in south-eastern, western and central parts of the study area. Factor 4 is influenced by $\mathrm{CO}_{3}$ with $11.8 \%$ of variance, and the factor score spatial distribution map shows that the positive loading is found in central, eastern and southern sides of the study area. Factor 1 of IAWH (Fig. 15) accounting for about $37.5 \%$ of the variance is explicitly showing high loadings on the ions of $\mathrm{Na}, \mathrm{Ca}$, $\mathrm{Cl}, \mathrm{EC}$ and TDS, and the areal distribution map shows that the south-eastern, north-eastern and central-eastern parts are affected with regard to the positive score and in that, shrimp farming area is $0.34 \mathrm{~km}^{2}$. Factor 2 represented by 
Fig. 16 Dendrogram of Q- and $\mathrm{R}$-mode hierarchical cluster analysis (PC) (a) $\mathbf{R}$ mode

Rescaled Distance Cluster Corbine

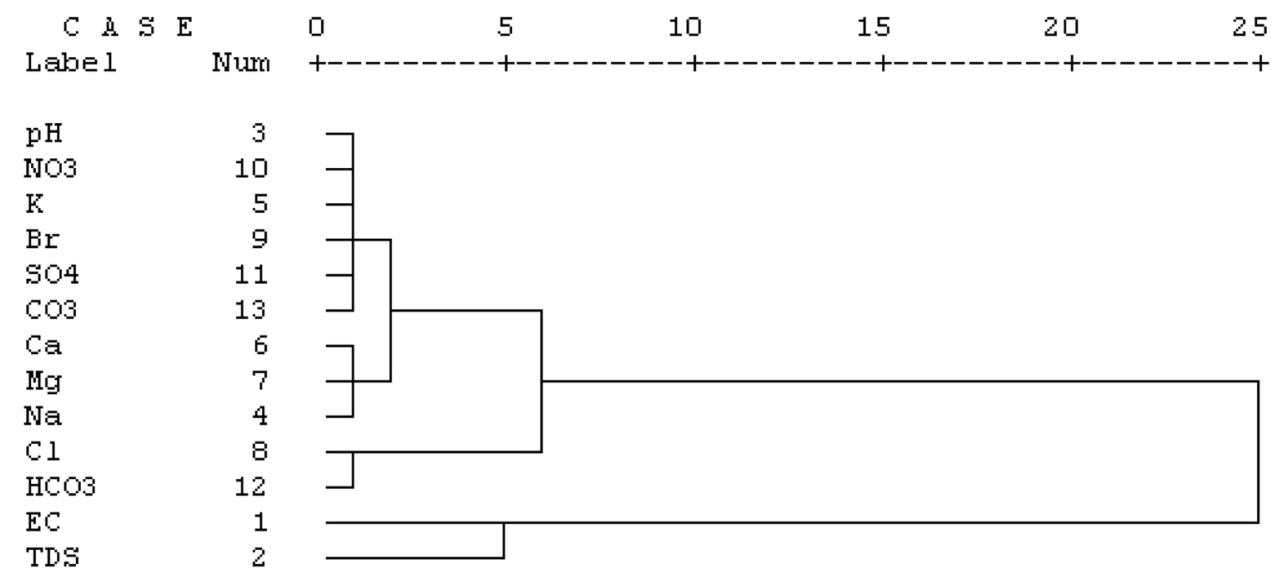

(b) $Q$ mode

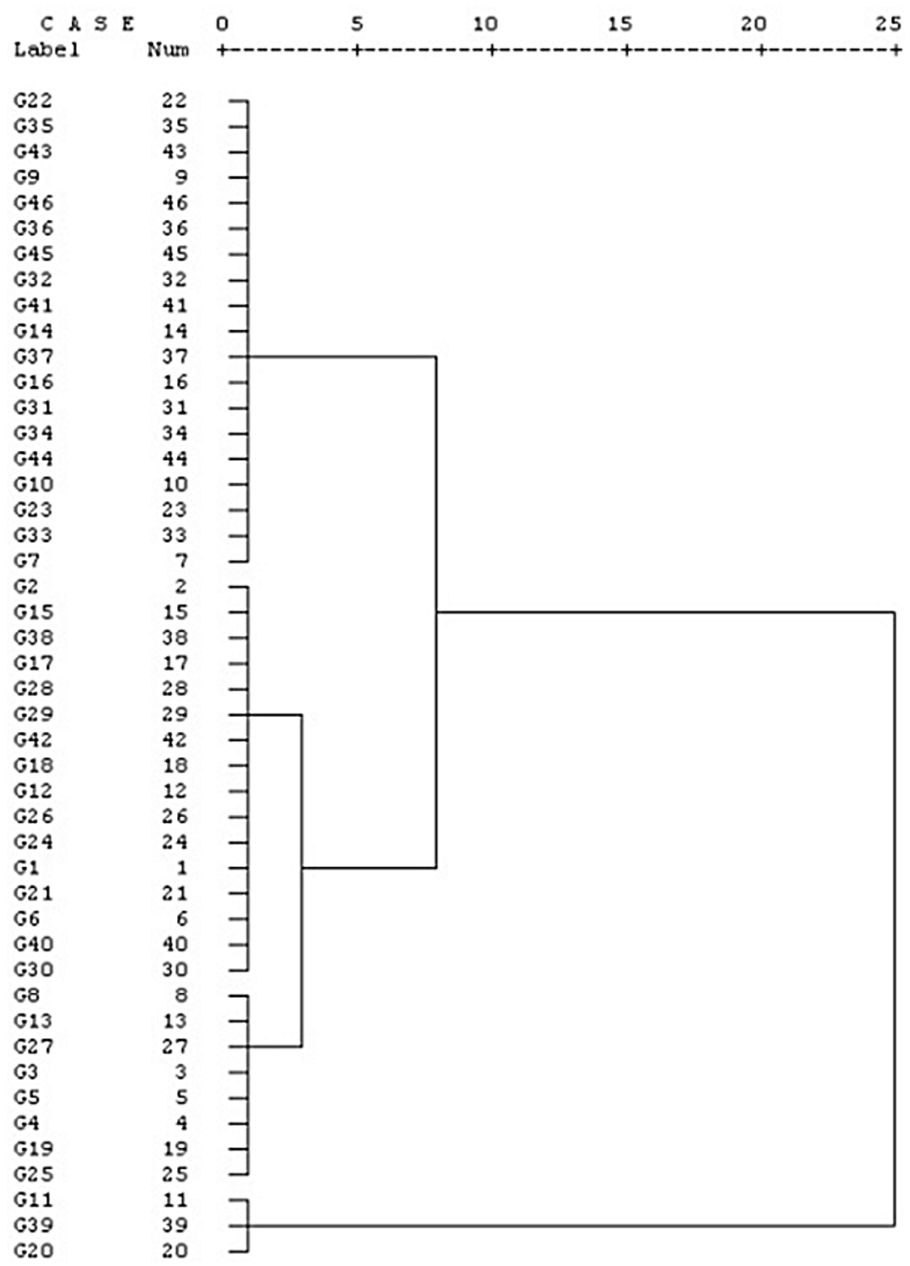

$\mathrm{CO}_{3}$ and the factor score of spatial distribution map shows that the positive loading is found in south-western and north-eastern sides of the study area. Factor 3 indicates the enrichments of $\mathrm{HCO}_{3}$, and areal distribution map shows high positive scores at the south-western and north-eastern sides of the study area. There is no high loading observed in factor 4, and the areal map suggests that the wells in the south-eastern sides are dominated in high positive scores. 
Fig. 17 Dendrogram of Q- and $\mathrm{R}$-mode hierarchical cluster analysis (SC)

\section{(a) $\mathbf{R}$ mode}

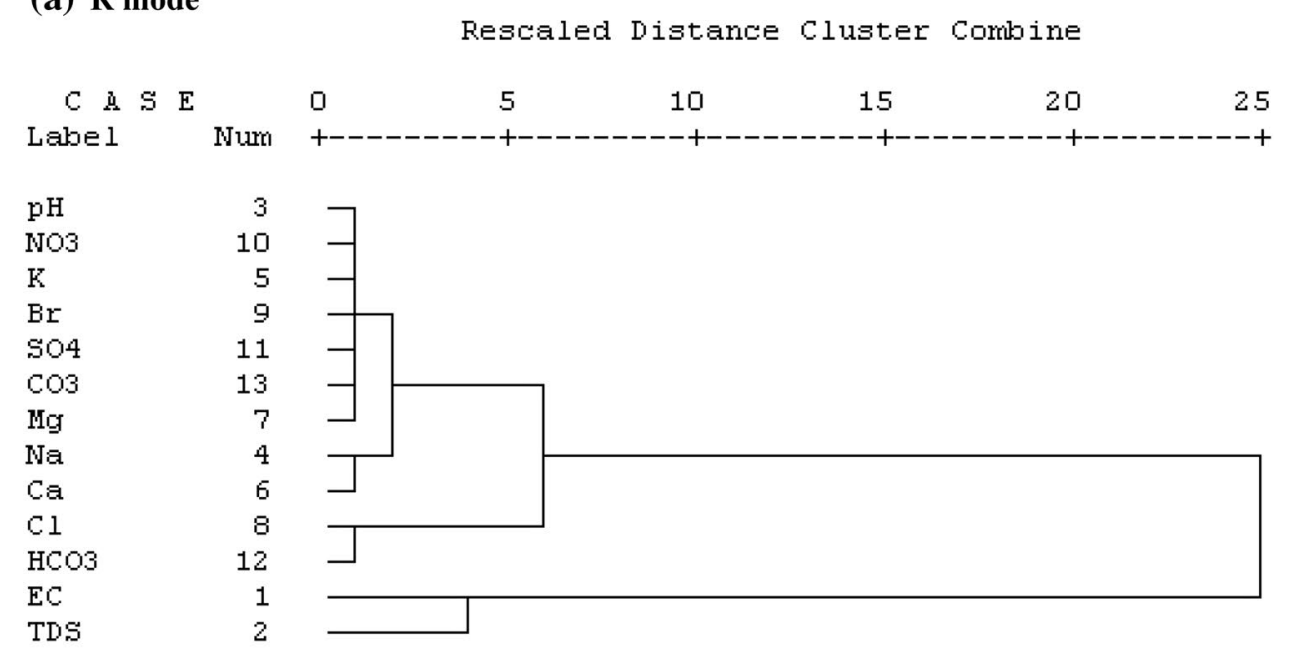

(b) $\mathbf{Q}$ mode
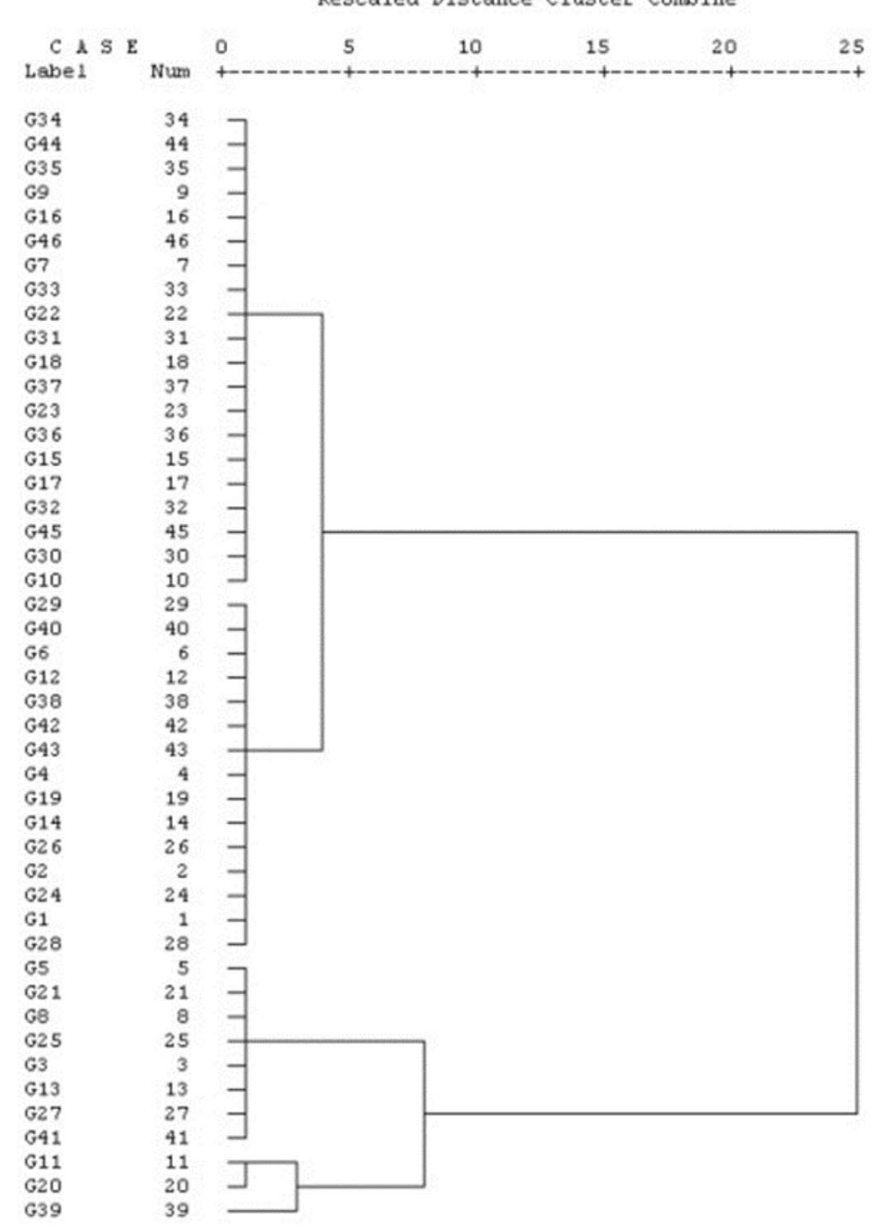

\section{Hierarchical cluster analysis}

In this study, hierarchical cluster analysis (HCA) was used to determine the association between sampling sites, because it provides an indication of similarities/dissimilarities between the water quality parameters (Das and Nag 2017). Recent studies have been focused on both Q-mode and R-mode, which were performed for hydrogeochemical parameters. The Q-mode HCA was used to classify the samples into distinct hydrogeochemical groups, while R-mode HCA 
Fig. 18 Dendrogram of Q- and $\mathrm{R}$-mode hierarchical cluster analysis (IASH) (a) $\mathbf{R}$ mode

Rescaled Distance Cluster Combine

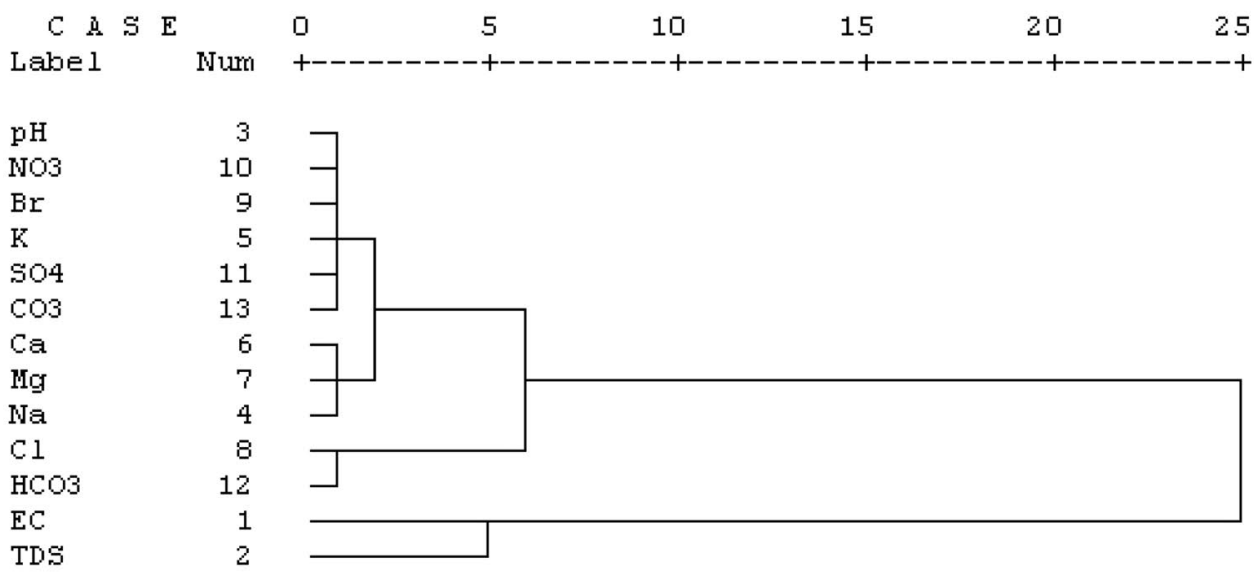

(b) Q mode
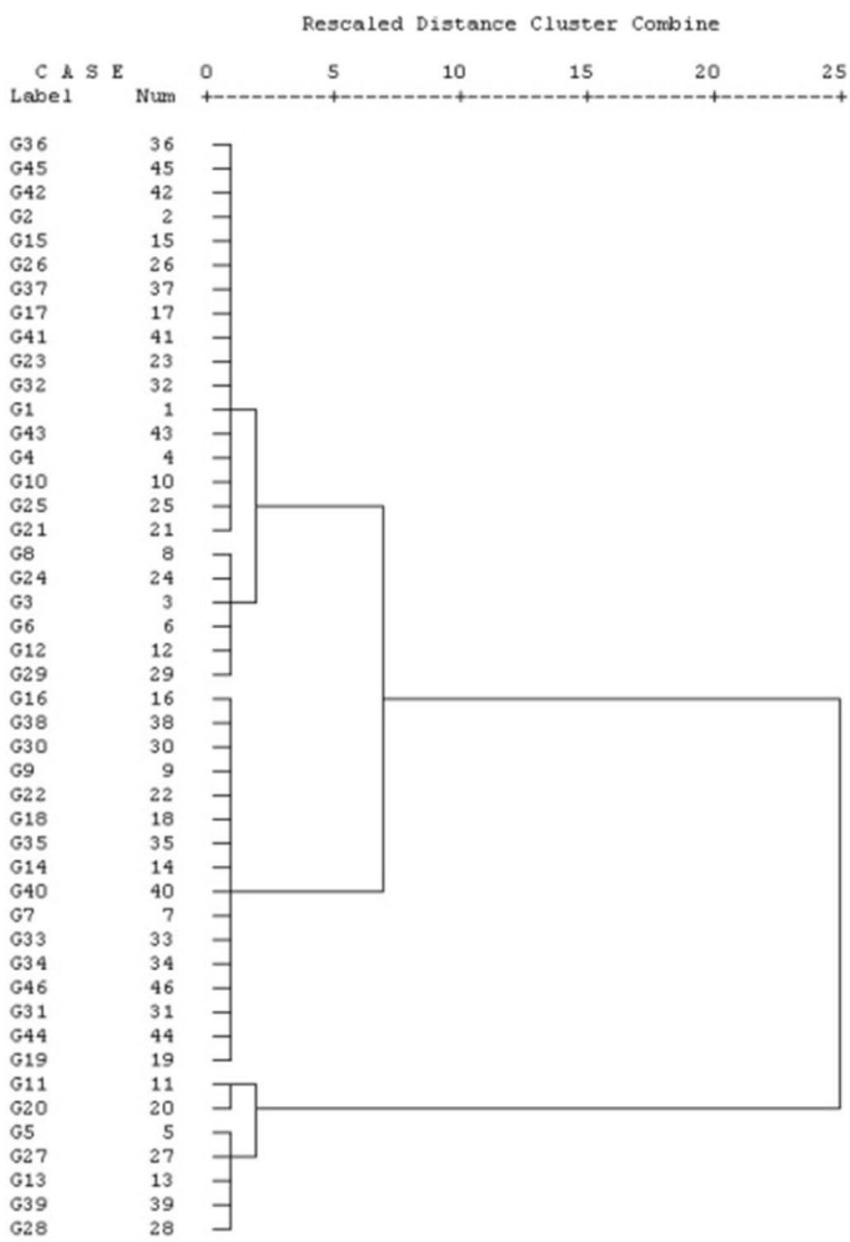

linking the variables (Loganathan and Jafar Ahamed 2017). In this study, Q-mode and R-mode produced a dendrogram chart obtained from Ward's linkage method for grouping the groundwater samples. Figures 16a, 17a, 18a, 19a and 20a show that the similar result is obtained in different culture periods with a very little variation among samples in second sub-cluster of R-mode hierarchical cluster analysis. Based on the figures, two main clusters can be identified among physicochemical variables for different culture periods. The first cluster is accompanied by EC and TDS. These variables are 
Fig. 19 Dendrogram of Q- and $\mathrm{R}$-mode hierarchical cluster analysis (WC)

\section{(a) $\mathbf{R}$ mode}

Rescaled Distance Cluster Combine

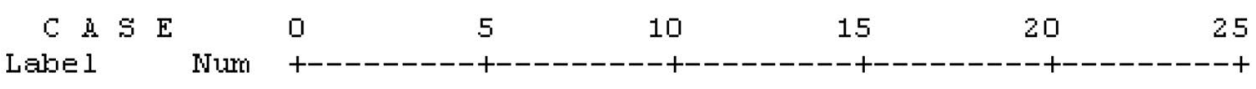

$\begin{array}{lr}\mathrm{K} & 5 \\ \mathrm{NO} & 10 \\ \mathrm{pH} & 3 \\ \mathrm{Br} & 9 \\ \mathrm{SO} & 11 \\ \mathrm{CO} 3 & 13 \\ \mathrm{Ca} & 6 \\ \mathrm{Mg} & 7 \\ \mathrm{Na} & 4 \\ \mathrm{Cl} & 8 \\ \mathrm{HCO} & 12 \\ \mathrm{EC} & 1 \\ \mathrm{TDS} & 2\end{array}$

(b) Q mode

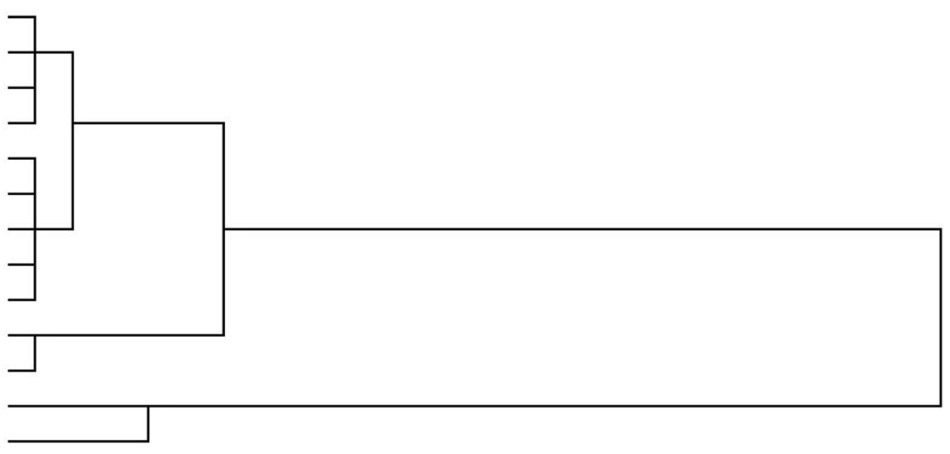

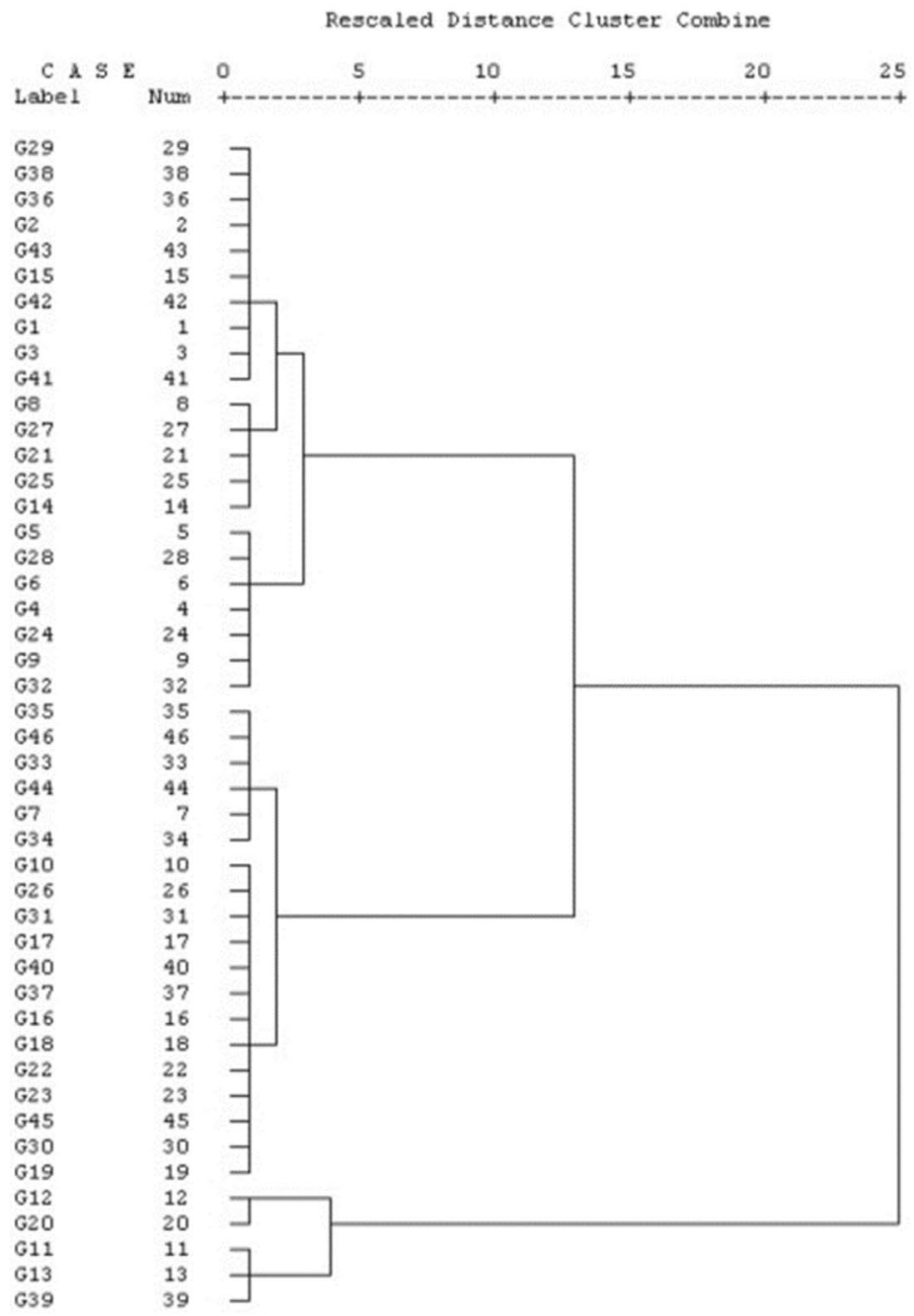

affected mainly by salinity factor due to seawater intrusion into coastal aquifer (Venkatramanan et al. 2017). The second cluster consists of 11 variables, and it is further classified into two more clusters. $\mathrm{HCO}_{3}$ and $\mathrm{Cl}$ make the first subcluster, and $\mathrm{Ca}, \mathrm{Mg}, \mathrm{K}, \mathrm{Na}, \mathrm{CO}_{3}, \mathrm{SO}_{4}, \mathrm{NO}_{3}, \mathrm{Br}$ and $\mathrm{pH}$ make the second sub-cluster. Second cluster is not homogenous 
Fig. 20 Dendrogram of Q- and $\mathrm{R}$-mode hierarchical cluster analysis (IAWH) (a) $\mathbf{R}$ mode

Rescaled Distance Cluster Combine

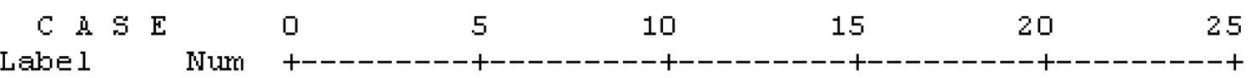

$\mathrm{pH}$
$\mathrm{NO} 3$
$\mathrm{~K}$
$\mathrm{Br}$
$\mathrm{SO} 4$
$\mathrm{CO} 3$
$\mathrm{Ca}$
$\mathrm{Mg}$
$\mathrm{Na}$
$\mathrm{Cl}$
$\mathrm{HCO}$
$\mathrm{EC}$
$\mathrm{TDS}$

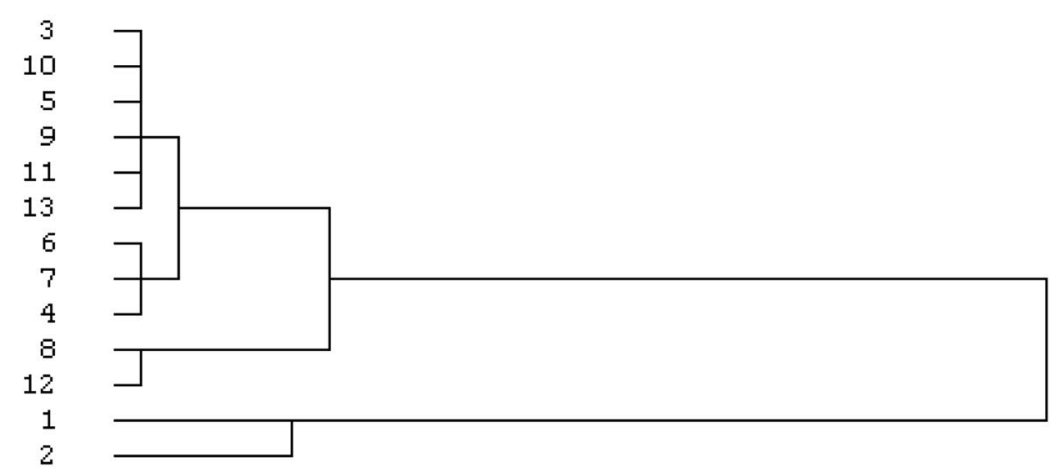

(b) Q mode

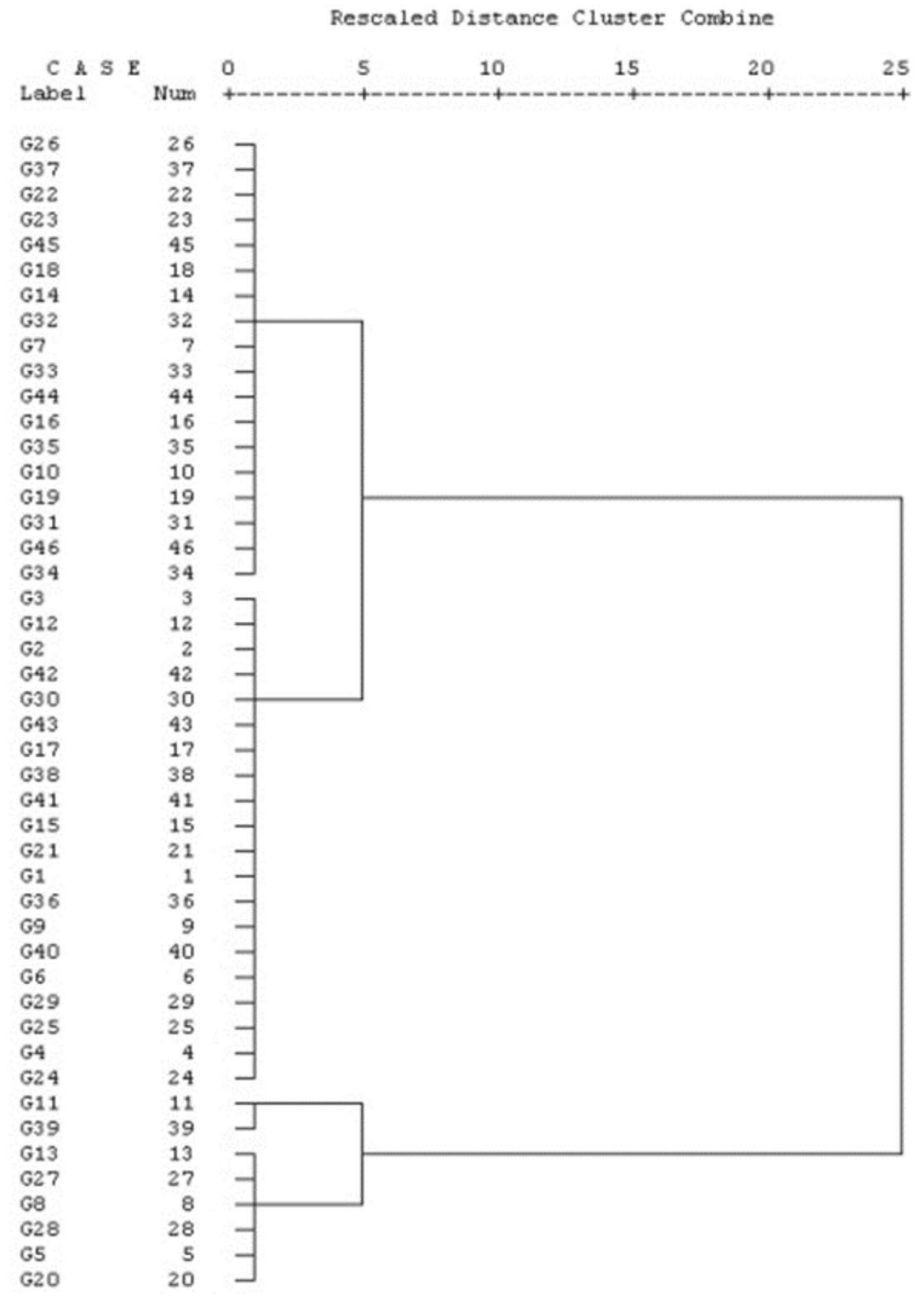

and influenced by multiple factors which are influencing the geochemistry of groundwater (Rekha et al. 2013). In Q-mode analysis, all the culture periods are classified into two major groups. The results of PC (Fig. 16b) show that the first cluster comprises three samples (G11, G20 and G39) with the mean value of TDS $4200 \mathrm{mg} / \mathrm{l}$ and occupies $6.5 \%$ 
of the groundwater samples. This cluster is characterized as high saline water intrusion, and sampling of this cluster was not located together, but it lies near to the creek. The second cluster is concerned with $93.5 \%$ and 43 samples, which indicate fresh groundwater with a mean TDS value of $1191.28 \mathrm{mg} / \mathrm{l}$ due to surface water recharge and water-rock interaction. Groundwater sample wells (G6, G9, G12, G22, G26, G32, G33, G40 and G42) are observed near to the shrimp farming area. A similar pattern is observed in the study area during SC, IASH, WC and IAWH culture periods (Figs. 17b, 18b, 19b, 20b) with a slight variation. It concludes that the majority of shrimp farming area are located in the second cluster.

\section{Conclusion}

The present study explains about integrated hydrogeochemical characterization and multivariate statistical methods to examine the groundwater quality in shrimp farming area. From the above statement, it is inferred that the abundance of cations and anions was in the order of $\mathrm{Na}>\mathrm{Ca}>\mathrm{Mg}>\mathrm{k}$ and $\mathrm{Cl}>\mathrm{HCO}_{3}>\mathrm{SO}_{4}>\mathrm{CO}_{3}>\mathrm{NO}_{3}>\mathrm{Br}$ during different culture periods, respectively. The spatial distribution map of EC and TDS values for different culture periods shows that the higher concentration was noted near to the creek and along the coastal region suggesting the significant intrusion of seawater into the aquifer system. The Piper plot revealed that there is no significant change in the hydrogeochemical facies during different culture periods, and the chemical composition of the groundwater was controlled by ion exchange reactions. Moreover, Chadha's classification revealed that the reverse ion exchange was the dominant feature, and it is supported by various ionic indices such as $\mathrm{Na} / \mathrm{Cl}$ versus $\mathrm{EC},(\mathrm{Ca}+\mathrm{Mg})$ versus $\left(\mathrm{SO}_{4}+\mathrm{HCO}_{3}\right)$, $(\mathrm{Na}-\mathrm{Cl})$ versus $\left(\mathrm{Ca}+\mathrm{Mg}-\mathrm{HCO}_{3}-\mathrm{SO}_{4}\right),(\mathrm{Ca}+\mathrm{Mg})$ versus $\mathrm{Cl}$ and $\mathrm{Na} / \mathrm{Cl}$ versus $\mathrm{Cl}$, respectively. Based on the results obtained from the factor analysis, it clearly illustrates the multiple factors responsible for groundwater quality. During different culture periods, factor 1 is dominated by high loading of $\mathrm{Na}, \mathrm{Cl}, \mathrm{Br}, \mathrm{EC}$ and TDS of variance indicating the intrusion of seawater into the aquifer system. The spatial distribution map of factor scores clearly delineates that the positive values are observed near to the creek and sea, which are in the north-eastern, south-eastern and centraleastern parts of the study area and in that, shrimp farm area is very less. Cluster analysis also highlights that there is petite culture variation among the samples and variables. The result of R-mode analysis consists of two clusters for different culture periods: the first cluster consists of EC and TDS, and the second cluster is accompanied by 11 variables; it shows multiple factors which are influencing the geochemistry of groundwater. Q-mode analysis shows that all the culture periods are classified into two major clusters: the first cluster is characterized as high saline water intrusion, and sampling of this cluster was not located together, but it lies near to the creek. The second cluster associated with water-rock interaction and anthropogenic resources comprises that samples, namely G6, G9, G12, G22, G26, G32, G33, G40 and G42, were observed near to the shrimp farming area with slight variations. The above methods revealed that there is no significance change between the culture periods, and it mainly depends upon the geological process.

Acknowledgements This project was funded by the Ministry of Water Resources (MoWR), Government of India, which is gratefully acknowledged (No. 29/INCGW-04/2010-R\&D/2967-2976 Dated: 24-12-2010). The authors sincerely thank Dr. P. Ravichandran, former Head, CCD Division and Dr. A.G. Ponniah, former Director, Central Institute of Brackishwater Aquaculture (CIBA), for their continuous support in bringing out this research work.

Open Access This article is distributed under the terms of the Creative Commons Attribution 4.0 International License (http://creativeco mmons.org/licenses/by/4.0/), which permits unrestricted use, distribution, and reproduction in any medium, provided you give appropriate credit to the original author(s) and the source, provide a link to the Creative Commons license, and indicate if changes were made.

\section{References}

APHA (2005) Standard methods for the examination of water and waste water, 21st edn. American Public Health Associations, Washington, p p1368

Chidambaram S, Ramanathan AL, Prasanna MV, Karmegam U, Dheivanayagi RR, Johnsonbab G, Premchander B, Manikandan S (2010) Study on the hydrogeochemical characteristics in groundwater, post and pre tsunami scenario from Portnova to Pumpuhar, southeast coast of India. Environ Monit Assess 169:553-568

Das S, Nag SK (2017) Application of multivariate statistical analysis concepts for assessment of hydrogeochemistry of groundwater-a study in Suri I and II blocks of Birbhum District, West Bengal, India. Appl Water Sci 7:873-888. https://doi. org/10.1007/s13201-015-0299-6

Datta PS, Bhattacharya SK, Tyagi SK (1996) 180 studies on recharge of phreatic aquifers and groundwater flow-paths of mixing in Delhi area. J Hydrol 176:25-36

Domenico PA, Schwartz FW (1998) Physical and chemical hydrogeology, 2nd edn. Wiley, New York, p 506

Elango L, Kannan R, Senthil Kumar M (2003) Major ion chemistry and identification of hydrogeochemical processes of groundwater in a part of Kancheepuram district, Tamil Nadu, India. J Environ Geosci 10(4):157-166

Fisher RS, Mulican WF III (1997) Hydrochemical evolution of sodium-sulphate and sodium-chloride groundwater beneath the Northern Chihuahuan desert, Trans-Pecos, Texas, USA. Hydrogeol J 5(2):4-16

Gangadharan R, Rekha PN, Vinoth S (2016) Assessment of groundwater vulnerability mapping using AHP method in coastal watershed of shrimp farming area. Arab J Geosci 9:107. https ://doi.org/10.1007/s12517-015-2230-8 
Ghabayen S, Mckee M, Kemblowski M (2006) Ionic and isotopic ratios for identification of salinity sources and missing data in the Gaza aquifer. J Hydrol 318:360-373

Giridharan L, Venugopal T, Jayaprakash M (2009) Assessment of water quality using chemometric tools: a case study of River Cooum, South India. Arch Environ Contam Toxical 56:654-669

Janardhana Raju N (2006) Seasonal evaluation of hydro-geochemical parameters using correlation and regression analysis. Curr Sci 91(6):820-826

Karmegam U, Chidambaram S, Sasidhar P, Manivannan R, Manikandan S, Anandhan P (2010) Geochemical characterization of groundwaters of shallow coastal aquifer in and around Kalpakkam, South India. Res J Environ Earth Eci 2(4):170-177

Loganathan K, Jafar Ahamed A (2017) Multivariate statistical techniques for the evaluation of groundwater quality of Amaravathi River Basin: South India. Appl Water Sci 7:4633-4649. https ://doi.org/10.1007/s13201-017-0627-0

Meybeck M (1987) Global chemical weathering from surficial rocks estimated from river dissolved loads. Am J Sci 287:401-428

Mor S, Ravindra K, Dahiya RP, Chandra A (2006) Leachate characterization and assessment of groundwater pollution near municipal soild waste landfill site. Environ Monit Assess 118(1-3):435-456

MPEDA (2014) Marine products export development authority. Press release exports 2013-14. http://pib.nic.in/newsite/PrintRelea se. aspx? relid $=105298$

Murugesan P, Ajithkumar TT, Ajmal Khan S, Balasubramanian T (2009) Use of benthic biodiversity for assessing the impact of shrimp farming on environment. J Environ Biol 30(5):856-870

Newport JK, Jawahar GGP (1995) Brackish water shrimp farming culture; impact on eco-environment and socio-economic aspects of rural fisher folk. Fish Chimes 15:15-16

Patil AA, Annachhatre AP, Tripathi NK (2002) Comparison of conventional and geospatial EIA: a shrimp farming case study. Environ Impact Assess Rev 22(4):361-375

Phillips MJ, Lin CK, Beveridge (1993) Shrimp culture and environment: lessons from the most rapidly expanding warm water aquaculture sector. In: Pullin RSV, Rosenthal H, Maclean JL (eds) Environment and aquaculture in developing countries ICLARM conference processing, 36, pp 171-197 (359)

Prasanna MV, Chidambaram S, Senthil Kumar G, Ramanathan AL, Nainwal HC (2011) Hydrogeochemical assessment of groundwater in Neyveli Basin, Cuddalore district, South India. Arab J Geosci 4:319-330

Rajmohan N, Elango L (2001) Modelling the movement of chloride and nitrogen in the unsaturated zone. In: Elango L, Jayakumar R(eds) Modelling in hydrogeology (Proc United Nations Educational, Scientific and Cultural Organization-International Hydrological Program (UNESCO-IHP)) Allied, New Delhi, India, pp 209-225

Rekha PN, Ravichandran P, Gangadharan R, Bhatt JH, Panigrahi A, Pillai SM, Jayanthi M (2013) Assessment of hydrogeochemical characteristics of groundwater in shrimp farming areas in coastal Tamil Nadu, India. Aquac Int. https://doi.org/10.1007/s1049 9-012-9618-1

Rekha PN, Gangadharan R, Ravichandran P, Mahalakshmi P, Panigrahi A, Pillai SM (2015) Assessment of impact of shrimp farming on coastal groundwater using Geographical Information System based Analytical Hierarchy Process. Aquaculture 448:491-506

Rekha PN, Gangadharan R, Ravichandran P, Dharshini S, Clarke W, Pillai SM, Panigrahi A, Ponniah AG (2017) Land-use/land-cover change dynamics and groundwater quality in and around shrimp farming area in coastal watershed, Cuddalore district, Tamil Nadu, India. Curr Sci. https://doi.org/10.18520/cs/v113/i09/1763-1770

Rogers RJ (1989) Geochemical comparison of groundwater in areas of New England, New York and Pennsylvania. Groundwater 27(5):690-712

Saraswathy R, Ravisankar T, Ravichandran P, Deboral Vimala D, Jayathi M, Muralidhar M, Manohar C, Vijay M, Santharupan TC (2016) Assessment of soil and source water characteristics of disused shrimp ponds in selected coastal states of India and their suitability for resuming aquaculture, Indian. J Fish 63(2):118-122

Senthilkumar S, Balasubramanian N, Gowtham B, Lawrence JF (2017) Geochemical signatures of groundwater in the coastal aquifers of Thiruvallur district, South India. Appl Water Sci 7:263-274

Seshadri H, Kaviyarasan R, Sasidhar P, Balasubramaniyan V (2013) Effect of saline water bodies on the hydrogeochemical evaluation of groundwater at Kalpakkam Coastal site, Tamil Nadu. J Geol Soc India 82(5):535-544

Shigut DA, Liknew G, Irge DD, Ahmad T (2017) Assessment of physico-chemical quality of borehole and spring water sources supplied to Robe Town, Oromia region, Ethiopia. Appl Water Sci 7:155-164

Singaraja C, Chidambaram S, Prasanna MV, Thivya C, Thilagavathi R (2013) Statistical analysis of the hydrogeochemical evolution of groundwater in hard rock coastal aquifer of Thoothukudi district in Tamilnadu, India. Environ Earth Sci. https://doi.org/10.1007/ s12665-013-2453-5

Singaraja C, Chidambaram S, Anandhan P, Prasanna MV, Thivya C, Thilagavathi R (2014) A study on the status of saltwater intrusion in the coastal hard rock aquifer of South India. Environ Dev Sustain. https://doi.org/10.1007/s10668-014-9554-5

Subramani T, Elango L, Damodarasamy SR (2005) Groundwater quality and its suitability for drinking and agricultural use Chithar River Basin, Tamil Nadu, India. Environ Geol 47:1099-1110

Vandenbohede A, Courtens C, William de Breuck L (2010) Fresh-salt water distribution in the central Belgian coastal plain: an update. Geol Belg 11(3): 163-172

Vengosh A, Gill J, Davisson ML, Huddon GB (2002) A multi isotope $(\mathrm{B}, \mathrm{Sr}, \mathrm{O}, \mathrm{H}, \mathrm{C})$ and age dating $(3 \mathrm{H}-3 \mathrm{He}, 14 \mathrm{C})$ study of groundwater from Salinas Valley, California: hydrochemistry, dynamics and contamination processes. Water Resour Res 38(9):1-17

Venkatramanan S, Chung SY, Ramkumar T, Gnanachandrasamy G, Vasudevan S (2017) A multivariate statistical approaches on physicochemical characteristics of groundwater in and around Nagapattinam district, Cauvery deltaic region of Tamil Nadu, India. Earth Sci Res 17(2):97-103

Publisher's Note Springer Nature remains neutral with regard to jurisdictional claims in published maps and institutional affiliations. 